\title{
On the current state of taxonomy of the Baikal Lake amphipods (Crustacea: Amphipoda) and the typological ways of constructing their system
}

\section{О современном состоянии таксономии байкальских амфипод (Crustacea: Amphipoda) и типологическом способе построения их системы}

\author{
V.V. Takhteev ${ }^{1,2}$ \\ B.B. Тахтеев ${ }^{1,2}$ \\ ${ }^{1}$ Department of Biological and Soil Science at Irkutsk State University, Karl Marx St. 1, Irkutsk 664003, Russia.
E-mail: Amphipoda@yandex.ru
${ }^{1}$ Иркутский государственный университет, биолого-почвенный факультет, ул. К. Маркса, 1, Иркутск 664003, Россия.
E-mail: Amphipoda@yandex.ru
${ }^{2}$ Baikal Museum of Irkutsk Scientific Center SB RAS, Akademicheskaya St. 1, Listvyanka Settl., Irkutsk Region 664520, Russia.
${ }^{2}$ Байкальский Музей Иркутского научного центра Сибирского отделения Российской академии наук, ул. Академическая, 1, пос.
Листвянка Иркутской обл. 664520, Россия.
}

KEY WORDS: amphipods, Lake Baikal, taxonomy, taxonomic inflation, archetype, core, deviations, establishment of families.

КЛЮЧЕВЫЕ СЛОВА: амфиподы, озеро Байкал, таксономия, таксономическая инфляция, архетип, ядро, отклонения, установление семейств.

\section{Editorial note \\ On the publication "On the current state of taxonomy of the Baikal Lake amphipods (Crustacea, Amphipoda) and the typological ways of constructing their system" by V.V. Takhteev}

In this issue we present an extensive article prepared by Prof. Vadim V. Takhteev, which is based on his long time effort in the study of diversity of amphipods in Lake Baikal and its watershed. This paper is highly polemical and may even seem either archaic or heretical in the time of domination of the phylogenetic paradigms in systematics. The author advocates classical morphological taxonomy, which own tradition, methods (disregarding whether we call it typology or not) and the language are significantly older than the modern phylogenetic approach. The phylogenetic approach simply could not come to being if classical taxonomy would not provide units for the analysis. This could be a commonplace, if not often having been forgotten.

The main reasons why we think, this paper is important are the following. First, this is an example of an open and explicit taxonomic discussion which becomes rare nowadays. The author consistently defends his approach to the macrosystematics of Baikal amphipods, comparing it to the approach of his opponent, Dr. R.M. Kamaltynov. We believe that there is room for constructive dialogue, and invite Dr. Kamaltynov to present his view in response to the criticism by Prof. Takhteev.

Secondly, the present paper emphasizes several pertinent problems of contemporary systematics usage of zoological nomeclature. The exceptional diversity of Baikal amphipods probably originated from several species of the genus Gammarus [Hou, Sket, 2016]. In such a case, if to follow the Hennigian logics, all Baikal amphipods must be included in Gammarus. This in turn, would make the genus useless as a taxon, because its diagnosis becomes similar to the diagnosis of the entire suborder Gammaroidea. Such paradox of the application of phylogenetic reconstruction to systematics is not unique, and is expected to be revealed where broad evolutionary radiation in the lineages originating from few pioneer species has taken place.

Fully realizing this, Hou and Sket [2016] propose to retain the Baikal amphipod genera even in the expense of accepting paraphyly of the genus Gammarus is by far more complex than our particular theories and concepts and Niels Bohr's complementarity is fundamental not only for quantum mechanics. Classical taxonomy and phylogenetic reconstrctions are complementary descriptions of reality as well. From this standpoint, Takhteev's rather conservative approach to the definition of families of Baikal amphipods is fully justified and has an undoubted cognitive value.

Finally, an issue of practical application of taxonomic databases like World Register of Marine Species (WoRMS) arises. The importance and value of WoRMS is globally recognized and can't be underestimated. However, the case of the Baikal 
amphipods clearly highlights the situation when the editors for a particular taxonomic group subjectively favor certain nomenclature acts and regard the alternative ones unaccepted. This is their right as the editors. However, we firmly believe that WoRMS is just a database and the exclusive use of names accepted there SHOULD NOT be mandatory in scientific publications, if the authors are capable to argue for validity of alternative nomenclature.

\section{References}

Hou Zh., Sket B. 2016. A review of Gammaridae (Crustacea: Amphipoda): the family extent, its evolutionary history, and taxonomic redefinition of genera // Zoological Journal of the Linnean Society. Vol.176. No.2. P.323-348.

Vassily A. Spiridonov, Kirill G. Mikhailov

\section{Комментарий редакторов \\ О пубцикации В.В. Тахтеева «О современном состоянии таксономии байкальских амфипод (Crustacea, Amphipoda) и типологическом способе построения их системы»}

В данном выпуске мы представляем обширную работу проф. В.В. Тахтеева, основанную на его многолетних исследованиях разнообразия амфипод озера Байкал и его бассейна. Эта статья написана весьма полемически и в наше время доминирования филогенетических парадигм в систематике может даже показаться, с одной стороны, архаичной, а с другой еретической. Автор выступает за классическую морфологическую таксономию, собственная традиция, метод (не важно, называем мы его типологическим, или нет) и язык которой значительно старше современного филогенетического подхода. Этот филогенетический подход просто не мог бы возникнуть, если бы классическая таксономия не поставляла ему единиц анализа. Это могло бы быть общим местом, если об этом обстоятельстве часто не забывали.

Почему мы думаем, что эта статья важна, должно быть понятно из следующего. Прежде всего, данная работа редкий в наши дни пример открытой и четко представленной таксономической дискуссии. Автор последовательно отстаивает оригинальный подход к макросистематике амфипод, сравнивая его с подходом своего оппонента Р.М. Камалтынова. Мы уверены, что здесь есть место для конструктивного диалога и приглашаем Р.М. Камалтынова представить свой ответ на критические замечания В.В. Тахтеева.

Далее, эта статья указывает на ряд действительных проблем современной систематики и использования зоологической номенклатуры. Все исключительное разнообразие байкальских амфипод происходит, весьма вероятно, от немногих видов рода Gammarus [Hou, Sket, 2016]. В этом случае, следуя хеннигианской логике, всех амфипод Байкала следовало бы отнести к этому роду. Но это сделало бы Gammarus бессмысленным в качестве таксона родовой категории, поскольку его диагноз практически соответствовал бы диагнозу всего подотряд Gammaroidea. Такого рода парадокс приложения филогенетической реконструкции к систематике не уникален: можно ожидать столкнуться с ним и в других случаях, когда мы имеем дело с широкой эволюционной радиацией в линиях, ведущих свое начало от немногих видов - пионеров новых местообитаний.

Полностью сознавая это, Хоу и Скет [Hou, Sket, 2016] предлагают сохранить роды байкальских амфипод, даже ценой парафилии Gammarus. Природа гораздо сложнее наших частных теорий и концепций, и дополнительность Нильса Бора имеет фундаментальное значение не только для квантовой физики. Классическая таксономия и филогенетическая реконструкция также являются дополнительными описаниями реальности. С этих позиций, достаточно консервативный подход Тахтеева к выделению семейств байкальских амфипод имеет несомненное познавательное значение.

Наконец, публикуемая статья указывает на важную проблему использования таксономических баз данных, таких как World Register of Marine Species (WoRMS). Важность и ценность WoRMS общепризнана и не может быть недооценена. В то же время случай байкальских амфипод высвечивает ситуацию, когда таксономические редакторы WoRMS по определенной группе субъективно признают одни номенклатурные акты и рассматривают другие как непринятые. Это их, редакторов, право. Однако мы твердо убеждены, что WoRMS это всего лишь база данных и использование исключительно принятых в нем названий НЕ ДОЛЖНО быть обязательным для научных публикаций, если авторы способны аргументировать валидность альтернативной номенклатуры.

\section{Литература}

Hou Zh., Sket B. 2016. A review of Gammaridae (Crustacea: Amphipoda): the family extent, its evolutionary history, and taxonomic redefinition of genera // Zoological Journal of the Linnean Society. Vol.176. No.2. P.323-348. 
It cannot be considered as a scientific

discovery of new galaxies, when they are created by splitting the galaxies that have long been known.

Нельзя считать научным открытием

новых галактик их создание

путем дробления галактик давно известных.

ABSTRACT. The state of macro-systematics of the Lake Baikal amphipods (354 species and subspecies) is critically reviewed. Their division into several families is advocated, despite the fact that all of them are nested within the molecular phylogenetic tree of the genus Gammarus. A historical essay of the arrangement of the Baikal amphipods to families by previous authors is provided. In the late XX to early XXI century a difficult situation arose with conflicting versions of the macrosystem: by Takhteev [2000, 2012, 2015] and Kamaltynov [1999, 2001, 2009]. The latter author did not describe any species using the own material but divided the amphipods of Lake Baikal into10 families and 13 non-nominative subfamilies, established 19 new genera, and raised 65 subspecies to the species rank. A critical review of taxonomical innovations by $\mathrm{Ka}$ maltynov as having no justification is given. A version of the Baikal amphipod system based on an archetypic approach is proposed. On the basis of this approach, archetypes and deviations of 7 families (including 6 families autochthonous for Baikal) with 3 subfamilies are described, and the key for definition of families on their core characteristics is provided.

How to cite this article: Takhteev V.V. 2019. On the current state of taxonomy of Baikal Lake amphipods (Crustacea, Amphipoda) and the typological ways of constructing their system // Arthropoda Selecta. Vol.28. No.3. P.374-402. doi: 10.15298/arthsel. 28.3.03

РЕЗЮМЕ. Критически проанализировано состояние макросистематики амфипод озера Байкал (354 вида и подвида). Обоснована целесообразность их подразделения на несколько семейств, несмотря на то, что все они при молекулярно-филогенетической реконструкции оказываются в пределах филогенетического древа рода Gammarus. Приведен исторический очерк того, как разные авторы рассматривали принадлежность байкальских амфипод к таксонам ранга семейства. В конце XX - начале XXI столетия возникла трудная ситуация, когда существуют одновременно два варианта макросистемы: В.В. Тахтеева [2000, 2012, 2015] и Р.М. Камалтынова [1999, 2001, 2009]. Последний автор, не описав на собственном материале ни одного вида, разделил амфипод Байкала на 10 семейств и 13 неноминативных подсемейств, установил 19 новых родов, 65 подвидов поднял в ранге до вида. Дается критика таксономических новаций Камалтынова как не имеющих обоснования. Предлагается вариант системы байкальских амфипод, основанный на архетипическом подходе. На основании этого подхода описаны архетипы и отклонения 7 семейств (из которых 6 - байкальские автохтонные) с 3 подсемействами, составлен ключ для определения семейств по их ядрам.

\section{Introduction}

Amphipods (Crustacea: Amphipoda) are one of the most prosperous groups of higher crustaceans in the fauna of the World Ocean, continental and underground water. In the early 1990s, about 6300 species were included in the order [Gruner et al., 1993]. Currently, according to an indicative estimate, their number is approaching 7000. The fauna of the Russian Federation includes 581 taxa of amphipod species from 26 families; $61 \%$ of this fauna (354 species and subspecies) falls on the autochthonous complex of Lake Baikal [Takhteev et al., 2015]. Baikal is the World's largest center of species accumulation and endemic speciation of freshwater amphipods. Even excluding the subspecies level taxa, Baikal hosts $4.3 \%$ of the world fauna of amphipods and $45.3 \%$ of amphipods inhabiting the superficial continental waters [Takhteev, 2000]. Life habits of the Baikal species, which formed many life forms, is also extremely diverse [Takhteev, 2000].

This article is devoted to the actual problems of taxonomy of amphipods of Lake Baikal, their family level classification, and the review of families, justified according to our approach.

Discussion on the number of Baikal amphipod families

The most important contribution to the description of the huge taxonomic diversity of the Baikal amphipods over the past century and a half has been made by B.I. Dybowsky [1874], V.P. Garjajew [1901], V.K. Sowinsky [1915], V.Ch. Dorogostajsky [1916, 1922, 1930, 1936], A.Ya. Bazikalova [1935, 1945, 1962, 1975, etc.], G.S. Karaman [1976, 1977], V.V. Takhteev [1995, 1997, 2000, etc.], M.E. Daneliya et al. [2014]. Several authors have proposed nomenclature changes without descriptions of new species and only on the basis of literary sources [Stebbing, 1899, 1906; Bousfield, 1977; Barnard, Barnard, 1983].

Paradoxically, when comparing the DNA sequences of amphipods from different regions of the planet, a huge morphological and ecological diversity, all Baikal amphipods should be genetically related not only to the single family Gammaridae, but even to the single genus Gammarus [Hou, Sket, 2016]. The above authors tentatively refer its origin to the middle of Neogene. Although a huge array of the genus Gammarus, consist- 
ing of several subclades, is generally well supported by molecular genetic data, and geographically clearly defined, these clades can not be hardly distinguished and characterized morphologically. They are extremely diverse. At the genetic level, Baikal genera, although they should be part of the genus Gammarus, fall into two distant subclades [Hou, Sket, 2016]. At the same time, hundreds of distinct species can be grouped in at least several families on the basis of their morphology.

How many of these families in Baikal are clearly different from each other? The debate on this issue has more than a century of history.

Benedict Dybowsky [1874], an outstanding pioneer of the studies of the Baikal amphipod fauna included all species and varieties (more than 100) in the Gammaridae and only in two genera: Gammarus Fabr. and Constantia Dyb. Dybowsky himself noted that this was done due to the lack of the necessary literature (he carried out his research in a political exile in the village of Kultuk on the shore of Lake Baikal) [Benedict Dybowsky, 2000].

Sometime later, T. Stebbing [1899] performed a revision of the Baikal amphipods of the genus Gammarus, rearranging the known species in 18 genera (16 of which were newly established). However, he still referred them to the Gammaridae.

V.P. Garjajew [1901] and V.K. Sowinsky [1915] made a major contribution to the knowledge of Baikal amphipods. Garjajew divided all amphipods occurring in Baikal into three subfamilies - Pachygammarinae (compact gammarids), Eugammarinae (real gammarids) and Acanthogammarinae (prickly gammarids). All of them, however, were also included in the family Gammaridae.

V.K. Sowinsky [1915] did not recognize supraspecific taxa, suggested by Garjajew [1901], considering all Baikal amphipods the within the monophyletic family Gammaridae. He wrote: "....None of the morphological features that characterize these groups (monoor poly-articulated accessory flagellum, the developments advance of the caudal segments and steering extremities, one- or two-branched structure of the latter), is not shared by all members of any group".

However, Sowinsky [1915] suggested that the only pelagic amphipod species in the Lake Baikal Macrohectopus branickii (Dybowsky, 1874) is so peculiar in its organization, it would deserve separation in the monotypic family Macrohectopidae (according to the personal comment of Prof. Ya.I. Starobogatov, grammatically correct spelling is Macrohectopodidae). Subsequently, for several decades, the issue of division of the Baikal amphipods into families was not even discussed. V.Ch. Dorogostajsky [1922, 1930, 1936] and A.Ya. Bazikalova $[1945,1962$, etc.] considered all of them within Gammaridae.

The issue of their division was once again put forward by E.L. Bousfield [1977] who presented his version of the solution within the framework of his world revision of the entire superfamily Gammaroidea. He published a graph showing that in the XX century there was an "extra-normal", exponential increase in the number of species and genera included in the "good old" Gammaridae. Indeed, according to the monograph by Barnard \& Barnard [1983], the number of known species of the genus Gammarus was 117, and now there are more than 200 [Hou et al., 2013]. Morphological construction plans of many of them strongly differ. Gammaridae clearly became an artificial group and needed a revision.

Bousfield splitted the Baikal species into four groups of the family rank. The first group considered as Gammaridae Leach, 1814, sensu str., included 4 subordinated subfamily groups, of which only one, Eugammarinae was named. Although this name has been used by Garjajew, Eugammarinae sensu Bousfield does not contain the Baikal Lake species. Other families in Bousfield's classification include Acanthogammaridae Garjajeff, 1901 (subfamily with the rank elevated to the family level), Macrohectopidae Sowinsky, 1915 (the name revalidated 62 years past its introduction by Sowinsky), and a unnamed group, including two genera, the Caspian Iphigenella and the Baikalian Pachyschesis. The artificiality of the latter unnamed group, linking the forms with subchelate arranged pereopods, was noticed by the author himself [Bousfield, 1977, p. 294].

Family Acanthogammaridae appeared in several subsequent publications by Bousfield [1982a,b]. Some other publications contain all four groups identified by Bousfield [Schram, 1986; Bousfield, Shih, 1994]. Recently even some fossils have been initially attributed to the Triassic "Acanthogammaridae" from Nevada [McMenamin et al., 2013]. Although, apparently, this fossil record does not belong to Amphipoda but Decapoda [Starr et al., 2015].

Of course, this first attempt of such a complex revision could not be perfect. It may be noted that not all genera included in the Acanthogammaridae correspond to its diagnosis; this family sensu Bousfield [1977] also includes two non-Baikalian, fossil genera (Praegmelina and Andrussovia). This probably needs a careful revision, the genus Gammaracanthus was subsequently referred by the same author to a separate family Gammaracanthidae, which has nothing to do with the Baikal fauna and contains no Baikal species [Bousfield, 1989].

Yet there was a breakthrough in a long-overdue debate. Importantly, Bousfield's revision of the Gammaridae led to their better taxonomic definition: the family has been no longer a "dump" for newly described genera.

Bousfield's point of view was not accepted by everyone. The authors of the fundamental monograph on freshwater amphipods of the World [Barnard, Barnard, 1983], did not accept his system, noting that the proposed taxa are not clearly separated from each other. They systematize all freshwater species by groups, having no nomenclatural status, and not even named in Latin (although the name of each group is derived from the Latin name of one of the genera included in its composition, i.e. Wekeliids, Hadziids, Micruropids, 
Table 1. Number of taxa of the family group in Baikal, adopted by various authors. Таблица 1. Количество таксонов группы ранга семейства в Байкале, по разным авторам.

\begin{tabular}{|c|c|c|}
\hline Author & Number of families & Number of subfamilies (without nominative) \\
\hline Sowinsky [1915] & 2 & 0 \\
\hline Bazikalova [1945, 1962, 1975] & 1 & 0 \\
\hline Bousfield [1977] & 4 & 1 \\
\hline Takhteev [2000] & 6 & 13 \\
\hline Kamaltynov [2001, 2009] & 10 & 3 \\
\hline Takhteev, this publication & 7 & 0 \\
\hline
\end{tabular}

Acanthogammarids). All Baikal amphipods are divided into 10 such groups: the group Heterogammarus, the group Fluviogammarus, the group Acanthogammarus, the group Brandtia, the group Baikalogammarus, the group Macropereiopus, the group Micruropus, the group Pachyschesis, the group Hyalellopsis and group Macrohectopus. Nevertheless, all of the Baikal genera were tentatively considered by Barnard and Barnard [1983] as part of the family Gammaridae until future revision.

The question was raised again in my study on the revision of the polymorphic genus Poekilogammarus and consideration of its relationships with other genera [Tachteew, 1995]. It has been shown that the genera Pallasea, Poekilogammarus, Hakonboeckia, Metapallasea, Leptostenus and Gymnogammarus form a natural group, distinct from other Baikal genera, which is proposed to deserve a family rank: Pallaseidae (the composition of the family is indicated in 1995, but the diagnosis was first published in 2000, so this family name is available since 2000). The extremely peculiar morphology of the pelagic Macrohectopus branickii allows, in my opinion, to consider it a representative of a special, monotypic family Macrohectopodidae [Tachteew, 1995]. The support for the recognition of the family Macrohectopodidae independently came from the detailed morphological and ecological study of $M$. branickii [Timoshkin et al., 1995].

In my subsequent work on taxonomy and intergeneric relationships of the genus Plesiogammarus it was noted that the genera Garjajewia, Paragarjajewia, Plesiogammarus and Kozhovia are well separated from the other genera within the family Acanthogammaridae but show close affinities within its own group. This group deserves the rank of a separate subfamily [Takhteev, 1997, p. 51].

The revision was further developed in my monograph [Takhteev, 2000]. There so-called archetypical approach was advocated for arranging genera to families. This works well for the taxa with fuzzy boundaries (see below). By selecting archetypes ("cores" of taxa) it was proposed to assign Baikal amphipods to 6 families: Gammaridae, Acanthogammaridae (with the sub- families Acanthogammarinae and Garjajewiinae), Pallaseidae, Carinogammaridae, Macrohectopodidae and Pachyschesiidae [Takhteev, 2000] (Table 1).

The system proposed by me was a refined version of Bousfield's [1977] system. The differences were as follows. Instead of the artificial group Iphigenella Pachyschesis, which lumped the Caspian and Baikal genera, having no available name, the family Pachyschesidae Tachteew, 1998 was proposed, which united only the Baikal endemic parasitic amphipods. Amphipods having cuticular armature, which were earlier considered within the family Acanthogammaridae, were divided into three families. Classical Acanthogammaridae sensu Takhteev, 2000 have long teeth directed upwards and laterally. In another family Pallaseidae the characteristics of armature is quite different. In particular, the most developed teeths on the metasome segments are not median, but lateral rows, while they are tilted back. In most of the representatives of the third family, Carinogammaridae, only the median row of armature is developed, and often weakly. As a result, the number of groups of family rank have increased from 4 to 6 .

In the recent publications by Daneliya et al. [2009, 2011, 2014], molecular genetic and morphological methods have been combined, and several particular taxonomic changes have been proposed. The issue of the number of amphipod families in the Lake Baikal is has not been raised by these authors.

Quite sensational was the publication of Hou and Sket [2016], who showed that at the molecular genetic level all Baikal amphipods fall in two clades not only within the single family Gammaridae, but also within the single genus Gammarus. Following cladistic principles, in order to avoid the paraphyly of the Gammaridae, Hou \& Sket [2016] propose to reject all Baikal amphipod families (but not genera), as well as the families Pontogammaridae and Typhlogammaridae. However, applying this logic consistently one would have to refer all Baikal species to the genus Gammarus, because a single clade unites representatives of the genus Gammarus and two Baikal subclades of amphipods [Hou, Sket, 2016: fig. 2]. We return then back 
to Dybowsky's times with a single genus, to which he referred all the species revealed by him. No morphological diagnosis is possible for this genus due to its extreme diversity... Even a cladistic dogmatist will unlikely dare to make such changes in the classification, which will become absolutely useless for description of diversity and evolutionary radiation of the Baikal amphipods.

\section{Two incompatible classifications}

One of the major problems that creates great difficulty for experts in Amphipoda and the Baikal fauna, is that two different family level classifications of the Baikal amphipods exist in the literature.

In a series of papers by R.M. Kamaltynov an attempt was made to revise the Baikal amphipods at the level of higher taxa, genera and families ("higher classification") [Kamaltynov, 1995, 1999, 2001, 2009; the last two publications were actually published in 2002 and 2010]. In these papers a number of new families and subfamilies were proposed (see below), 19 new genera were established (excluding substituted names). Sixty-five amphipod subspecies were raised by Kamaltynov to the species rank by introducing these innovations as "package", referring to the "biological" concept of the species (in a primitive sense: different subspecies of the same species should never occur together) and did not consider each individual case. While radically changing the system of Baikal amphipods, Kamaltynov [2001] simultaneously revised the Caspian fauna, establishing two new families (!) and providing differential diagnoses that fit just into three lines.

From a morphological standpoint, all these new taxa are justified insufficiently or not justified at all. Kamaltynov used the results of a historical immunochemical analysis by D.N. Taliev [1940], and the results of alloenzyme analysis, creating the first version of his system, which then included only 2 families [Kamaltynov, 1995]. Later, Kamaltynov mostly took as a basis the grouping obtained in the course of molecular genetic analysis in the late 1990s [Sherbakov et $a l ., 1998$, etc], and turned clades of phylogenetic reconstructions into nominal taxa. But these action shows inconsistency: Kamaltynov took into account some results of the molecular phylogenetic studies, and did not pay attention to others. Apparently this author did not have any theoretical basis for the changes he had made.

We have already repeatedly commented with criticism on the taxonomical innovations of Kamaltynov [Takhteev, 2000, 2012; Takhteev et al., 2015]. He takes into consideration some of those comments, in particular, the ones of the inconsistency of diagnoses of families and subfamilies in relation to the diagnoses giving to genera. However, apparently, this led to further fragmentation of taxonomic groups of family rank that can be seen from the following indicators (Table 2).
Table 2. The increase in the number of taxa of rank family, erected by R.M. Kamaltynov.

Таблица 2. Рост числа таксонов ранга семейства, выделяемых Р.М. Камалтыновым.

\begin{tabular}{|c|c|}
\hline Publication & $\begin{array}{c}\text { Total number of families } \\
\text { and subfamilies (in } \\
\text { parentheses; excluding } \\
\text { nominative) }\end{array}$ \\
\hline Kamaltynov, 1995 & $2(5$ or 6$)$ \\
\hline Kamaltynov, 1999 & $4(7)$ \\
\hline Kamaltynov, 2001 & $7(8)$ \\
\hline Kamaltynov, 2009 & $10(13)$ \\
\hline
\end{tabular}

In our view, this trend is abnormal. The presence of endemic families in a particular basin of the continental hydrosphere is already a basis for its ranking as a separate zoogeographical region - the highest regionalization unit [Starobogatov, 1970]. The presence of such a high number of families and subfamilies is too excessive even for such a biologically unique waterbody as Lake Baikal. Obviously, we are faced here with the case of "taxonomic inflation" associated with excessive fragmentation of taxa and overestimation (as a consequence, depreciation) of their ranks.

However, other specialists working with the Baikal (and not only Baikal) amphipods do not have time for this "evolution of views". We regularly receive requests from various scientific institutions for advice to sort out taxonomic confusion. Many colleagues are confused with the use choice between Takhteev's or Kamaltynov's system in the conditions of "taxonomic dual power".

There is clearly a need for detailed discussion of the criteria for the system of Amphipoda. They should provide, on one hand, possibilities for amphipod taxa identification and orientation in their diversity for a variety of specialists (ecologists, physiologists, biochemists, geneticists, etc.). On the other hand, relative taxonomic stability in the group should be provided in the mid-term. Such stability was, for example, achieved for several decades after the publication of a classical monograph by Bazikalova [1945]. One of the criteria for success in the taxonomists work should be the stability of the system: the newly described taxa should not lead to its alteration, being easily integrated into the existing framework. A permanent taxonomic mess is completely unacceptable.

The following analogy clarifies this. An outstanding astronomical discovery, probably similar to the establishment of a new taxonomic family, is the discovery of a new galaxy. However, it is not a scientific discovery to create new galaxies by splitting the "old ones". Moreover, it does not make sense for individual wandering stars located in intergalactic space (these are, in fact, peripheral objects) to give the status of independent galaxies.

Why do many taxonomists consider acceptable to give their peripheral objects the status of families, class- 
es, or even types (i.e., Foissner et al., 1988; Tikhonenkov et al., 2014, etc.) remains completely incomprehensible. What sense does make establishment of the family Baikalogammaridae by Kamaltynov [2001] with a single species Baikalogammarus pullus (Dybowsky, 1874), a representative of the monotypic genus? This species has two very distinctive features: relatively pronounced sexual dimorphism, with significantly larger sizes of the males, and antennal cone, bent down towards the mouth appendages. In other characters, it can be considered within Micruropodidae: small size, lack of cuticular armature and spines on the segments of urosoma, one-segmented adventitious flagellum of antenna 1.

As another example, Kamaltynov [1999] established the subfamily Eulimnogammarinae Kamaltynov, 1999 within the Acanthogammaridae. He specified in the diagnosis of Acanthogammaridae: "... body robust, carinated and toothed (mainly dorsally and also ventrolaterally)" (p. 935). The diagnosis of his subfamily Eulimnogammarinae specifies opposite: “... body laterally compressed, smooth" (p. 937). In this case, the diagnosis of a subordinated taxon contradicts the diagnosis of external, and this is not the only case. This contradiction was commented in my monograph [Takhteev, 2000]. In response to this, Kamaltynov [2001] simply raised the rank of his subfamily to the family Eulimnogammaridae. At the same time, the molecular phylogenetics respected by him did not play a role: according to this author, the family Gammaridae in Baikal is completely absent, although in some of his presentations at scientific conferences he argued that the Baikal genera and species come from this family. The question arises: why did the Gammaridae disappear from the lake after rich taxonomical "procreation"?

Without engaging directly with the material, Kamaltynov [1999] introduced in the nomenclature the "new" family Pachyschesidae. It has an erroneous diagnosis which indicates that the family is characterized by the presence of spines on the segments of the metaand urosoma. Thus, he repeats the error made Bazikalova [1945] in the description of the type species of the genus Pachyschesis ("pleo- and urosome with spines dorsally"). None of the 16 species of this genus has any spines, on the back side of segments there are only bristles. My opponent is also not confused by the fact that he violates the rules of professional ethics of taxonomist contained in the Code. He was aware that I was doing a revision of this genus, in which 12 species were described for the first time and one species fully reimplemented on the basis of neotype. However, a little earlier in the brief communication [Takhteev, 1998] I managed to cite the name of the new family and specify its key features (abstracts of conference papers prior to 2000 was recognized as a taxonomic publications). Therefore, according to the International Code of Zoological Nomenclature the authorship of this family is reserved for me: Pachyschesidae Tachteew, 1998.

In a normally constructed system, the number of taxa naturally decreases as their rank increases. Rough- ly speaking, there should not be as many families as genera, and as many genera as species. It is unlikely that such a system can be considered natural. For this reason, the same regularity pattern can usually be traced in the activity of a productive taxonomist. The number of species and subspecies described by such a professional expert is significantly more than the number of new genera and even more so - new families. That is, the results of the activities of taxonomists should be reflected "taxonomical pyramid" with the apex on top.

Table 3 presents the results of my taxonomic work for the period 1992-2014, in comparison with the number and pattern of taxonomic innovations of Kamaltynov. He established 19 (!) new families and subfamilies, not counting the nominative ones; as many new genera; besides of the 12 previously existing subgenera raised by him to genera. It is significant that 65 subspecies were raised to species. The argument for this was often the joint occurrence of subspecies in the same samples (sometimes in only one sample). It is clear that co-occurrence does not necessarily mean the absence of reproductive isolation and that many taxa generally have different seasonal timing of reproduction, etc. Each case of change in the rank of taxon needs a detailed justification, and it is unacceptable to change these ranks in a "package" of tens of taxa.

Kamaltynov avoids explanations the causes of numerous serious taxonomic changes, "shuffles" the composition of genera in families and subfamilies in each regular publication, and explaining this apparent inconsistency by the fact that his views "undergo evolution". In particular, the author does not explain his actions on the allocation of numerous new taxa of the rank of genera and families. In the description of a new genus, he rewrites a diagnosis of a type species, turning it into a generic. We cannot even discuss his taxonomic and nomenclature innovations, because there are no arguments for such discussion.

However, it is possible to notice that Kamaltynov has not described any new species, except for a few new names introduced by a simple reference to the drawings of individual parts of the animal body in the publications of A.Ya. Bazikalova (to recognize these "species" in the nature hardly can himself the author). The invalidity of these names is briefly justified in our previous publication [Takhteev et al., 2015]. Different parts of the body showed in figures in general can belong to different specimens. In addition, Article 13.1.1. of The International Code of Zoological Nomenclature prescribes that the new name to be published accompanied by a description or diagnosis with an indication of the key features. This condition was not fulfilled by Kamaltynov.

Despite the obvious inconsistencies and shortcomings of the system proposed by Kamaltynov, it was adopted in the work by J.K. Lowry and A.A. Myers [2013], which in itself caused controversy. On the basis of this publication, it was without any discussion accepted in the database World Register of Marine Species (WoRMS). After the publication of our list of 
Table 3. Changes in the taxonomy of Baikal amphipods published by V.V. Takhteev and R.M. Kamaltynov. Таблица 3. Таксономические изменения в группе байкальских амфипод, произведенные в публикациях В.В. Тахтеева и Р.М. Камалтынова.

\begin{tabular}{|l|c|c|}
\hline \multicolumn{1}{|c|}{ The rank of taxa } & $\begin{array}{c}\text { Innovations by } \\
\text { V.V. Takhteev }\end{array}$ & $\begin{array}{c}\text { Innovations by } \\
\text { R.M. Kamaltynov }\end{array}$ \\
\hline New families & 3 & 6 \\
\hline New subfamilies (excepting the nominative) & 1 & 13 \\
\hline New genera & 2 & 19 \\
\hline New subgenera (excepting the nominative) & 2 & 4 \\
\hline Subgenera, elevated in rank to genus & 3 & 3 \\
\hline $\begin{array}{l}\text { Genera and subgenera, restored revalidated from } \\
\text { the previously neglected }\end{array}$ & 2 & 12 \\
\hline New species and subspecies & $32^{*}$ & 10 \\
\hline Synonymized species and subspecies & 5 & 65 \\
\hline $\begin{array}{l}\text { Species and subspecies that are revalidated from } \\
\text { synonymies }\end{array}$ & 1 & 0 \\
\hline Subspecies elevated to the rank of species & 6 & \\
\hline Species reduced in rank to subspecies & 2 & \\
\hline
\end{tabular}

* Another one species was described from the tributaries of Lake Baikal.

** All these species are established without a detailed taxonomic description, as a result of the giving the species status to the previously known intraspecific variations (by reference to the drawings of individual appendages of the body), or simply mistakenly [Takhteev et al., 2015].

amphipod species of the continental waters of Russia, where our version of the system was given [Takhteev et al., 2015], not only everything remained unchanged in this database (i.e. according to Kamaltynov's nomenclature), but the page has been added where our species names were made synonyms to Kamaltynov's names, and the latter were recognized as valid without any explanation (WoRMS, 2019).

Editors and reviewers of many journals often refer to WoRMS, checking the taxonomic names in the submitted manuscripts and requiring the authors to use them according to this source. Although WoRMS is just an information and reference base, which may contain errors and contradictions and has no "legal" effect, as the International Code of Zoological Nomenclature has. Realizing that non-Russian specialists can be familiar with the Baikal fauna mainly by literature, and they do not understand the essence of our disagreements, then we describe what we propose for classification of the Amphipoda of Lake Baikal.

Neotypology: The classification methodology based on archetypes

Once again, we emphasize that the present work aims at maintaining maximum possible stability of the existing system, making changes only if there is sufficient justification for their need. This is why I currently did not review for the genera, which need additional detailed study, i.e., Eulimnogammarus [Takhteev, 2000] for which there are only plans for future revision [Bedulina et al., 2014].

It is important to mention that plant taxonomists have a system of conservation of existing names without the right to change them subsequently securing the stability of nomenclature. A well-known Russian theorist of systematics S.V. Meyen considered resistance of a system to the introduction of new characters as one of the most convincing criteria for the naturalness of the system [Meyen, Shreider, 1976; Meyen, 1978]. He proceeded from the same assumption: the system should not be changed without substantial reasons. This applies, in our opinion, to molecular phylogenetic research: grouping of genera in different branches of a phylogenetic reconstruction should not be a mandatory basis for separating them in different families. The facts of discrepancy of morphological taxonomy and molecular phylogenetic reconstructions are quite common. The most striking example is given above [Hou, Sket, 2016]. However, it's not the only one. A similar discrepancy has been found for the endemic amphipods of Lake Ohrid and its basin [Wysocka et al., 2013]. 
As for the problem of the relationship between the traditional constructive morphological systematics and molecular phylogenetics, we adhere to the principle of outstanding Russian biologists, V.N. Beklemishev [1994] and A.A. Lyubischev [1982]: the system comes primarily, phylogeny is secondary. Phylogeny can be reconstructed when there is a system of the group.

In this regard, the situation with the protist macrosystem is highly relevant. The structural-morphological system had been existing for a long time, based on the commonality of external features (although speculative reasoning about phylogenetic relationships between phyla were implied by the authors). In the last two decades, the traditional system was practically replaced by a molecular phylogenetic system, with a number of new phyla, having no clear morphological diagnoses [Keeling et al., 2005; Hackett et al., 2007; Baldauf, 2008, etc.]. As a result, significant difficulties arose in particular even for the practice of teaching the diversity of protists to students. However, these full taxonomic perturbations did not change the general ideas of the development of life on Earth.

Secondly, for species rich taxa (including many Baikal amphipods), there is an urgent need to develop more or less universal criteria for family-level systematization.

Such criteria can be developed within the typological direction in systematics. The typology is traditionally considered to classify taxa in terms of their essential properties [Shatalkin, 1988], and the task of the taxonomist is to identify such properties. Therefore, in the literature the typology was also referred to essentialism — "the dominant theory of classification for many centuries was based on Aristotelian logic" [Mayr, 1969, p. 66]. At the same time, there was a stereotype that typology was characteristic mainly for the preDarwinian time, and now the main criterion of system- atization are phylogenetic relations of species. However, as shown above, even at the present level of molecular phylogenetic reconstructions it is an extremely difficult task, and concepts of phylogeny of particular groups of organisms are regularly reviewed and clarified. Attempts to continuously refine the classification according to these concepts lead to taxonomic chaos (which is often close to collapse).

At the same time, most taxonomists, who discover and describe new taxa continue (consciously or unconsciously) to use the typological method. Therefore, in my opinion, it is necessary to rehabilitate typology in the modern classification science. This paradigm may be called neotypology.

We proceed from the assumption that taxon must necessarily be diagnosed, even if this taxon is established with the use of molecular phylogenetic analysis.

How to make a working diagnosis for a group with a great variability? Taxa can be objectively characterized both extensionally and intensionally; these terms are used in the sense of Shatalkin [1988]. ${ }^{1}$ The Baikal fauna provides a good example explaining the application of these terms. In order to establish an intensionally defined taxon, it is necessary to identify a group of characters (or even sometimes one character) peculiar only to the members of this group and not present outside it (Fig. 1). Many biologists think that all taxa above the species rank can be distinguished by the intensional way.

However, when classifying polymorphic and actively evolving groups, it is often impossible to identified even a single common character that is shared by

\footnotetext{
${ }^{1}$ Intensionally defined groups - systematic groups, allocated to a particular feature or system of features. In extensionally-defined groups, there is no such character, which would be available to all members, but the apparent similarity of some elements with other evidence of the relationship.
}

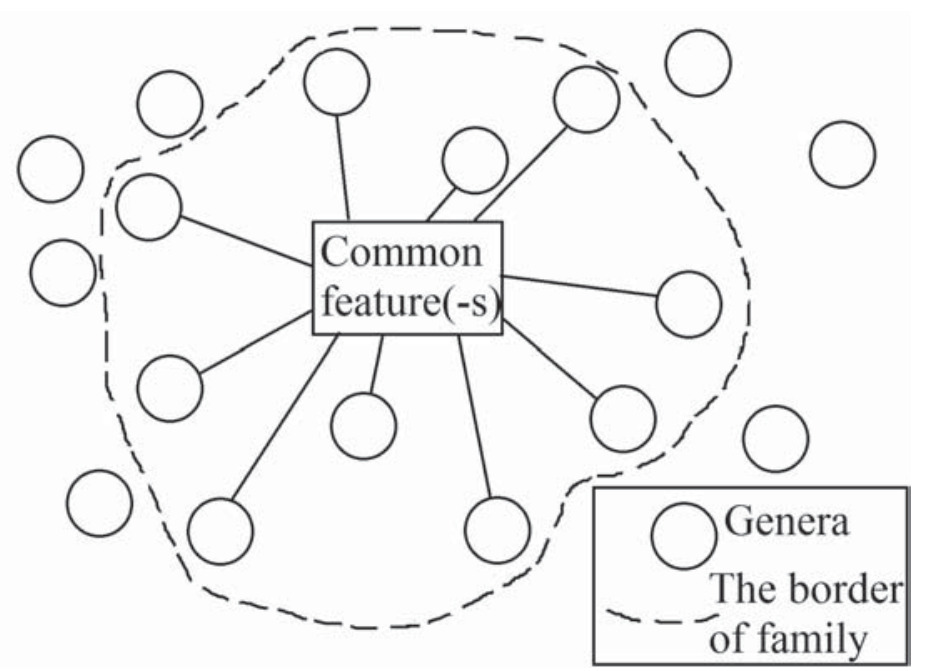

Fig. 1. A traditional intensional way of establishing a family rank taxon. A series of common (required) for it characters is delineated by a dashed line.

Рис. 1. Традиционный интенсиональный способ установления таксона ранга семейства. Серия общих (обязательных) для него признаков оконтурена прерывистой линией. 
all members of the group. The group, however, exists as extensionally defined taxon. Attempts to look for "only common characters" in such cases lead to unjustified fragmentation of taxa, the creation of a large abundance of oligo- or even monotypic groups. This phenomenon has already been mentioned: the taxonomic inflation, which, like economic inflation, is accompanied by a depreciation of taxonomic ranks, and their grinding. A clear indication of taxonomic inflation is an imbalance in the number of newly described species (and subspecies) and new taxa of higher rank. In our opinion, such situation has arisen in the taxonomy of amphipods of Lake Baikal due to the publications of Kamaltynov.

How extensional taxa which inner polymorphism actually reveals a unity, can be defined? Like members of a particular human family, such taxa are characterized by a set of characters that build up a collective image - the archetype. (This terms from Greek-derived words Arche, meaning origination; and Typos meaning form, pattern). There are deviations from the archetype, which should not be given a high taxonomic rank. These deviations are analogous to a style in the art. An archetype corresponds to the "core" of the taxon, and "stylistic" variation form its "periphery". "Stylistic" characteristics can overlap, or vary greatly and give the impression of a significant number of isolated "genera" and even "families"; but this is not the basis for an artificial increase in their rank. The above terminology was used by G.Yu. Lyubarsky [1996] and has already been adopted in popular manuals on biological systematics [Shipunov, 1999].

The archetypic approach is used intuitively by many taxonomists, even if they deny it [Lyubarsky, 1996]. However, it is important to identify clearly the charac- ters of the archetype core and deviations that indicate periphery of a taxon. We applied the archetypic approach in the revision of Baikal fauna of amphipods [Takhteev, 2000, 2012]. In our opinion, using this methodology provides a good chance to avoid taxonomic chaos and continual changes of the system and classification. This approach allows to distinguish taxa extensionally, based on the description of morphological archetypes (aggregates of the most characteristic features), and to exclude from the classification "stylistic" (rare) variation of the taxon periphery, i.e. avoiding their high taxonomic ranking. Thanks to this, it will be obvious that there is no point in moving the genera from one family to another and other changes in accordance with the personal "taste" of each taxonomist. The taxonomy and nomenclature will be stabilized for a relatively extended period.

Archetype and deviations are characterized separately in the diagnosis of taxon (family, subfamily). The archetype description is the formulation of "rules", and deviations are the enumeration of all identified exceptions to them. For example, if the core of the family Acanthogammaridae are armored amphipods, the prickliness is included in the description of the archetype. Species with smooth integument, but clearly close to the armoured genera (or certain species) have to be included in the list of deviations. The archetype is analogous to the internal border of the taxon, and the archetype along with deviations form its external border. Archetypes should be clearly (intensionally) separated from each other, deviative characteristics of particular families can overlap. It is such deviations for which splitting taxonomists assign unjustifiably high ranks (shaded gray region in Fig. 2).

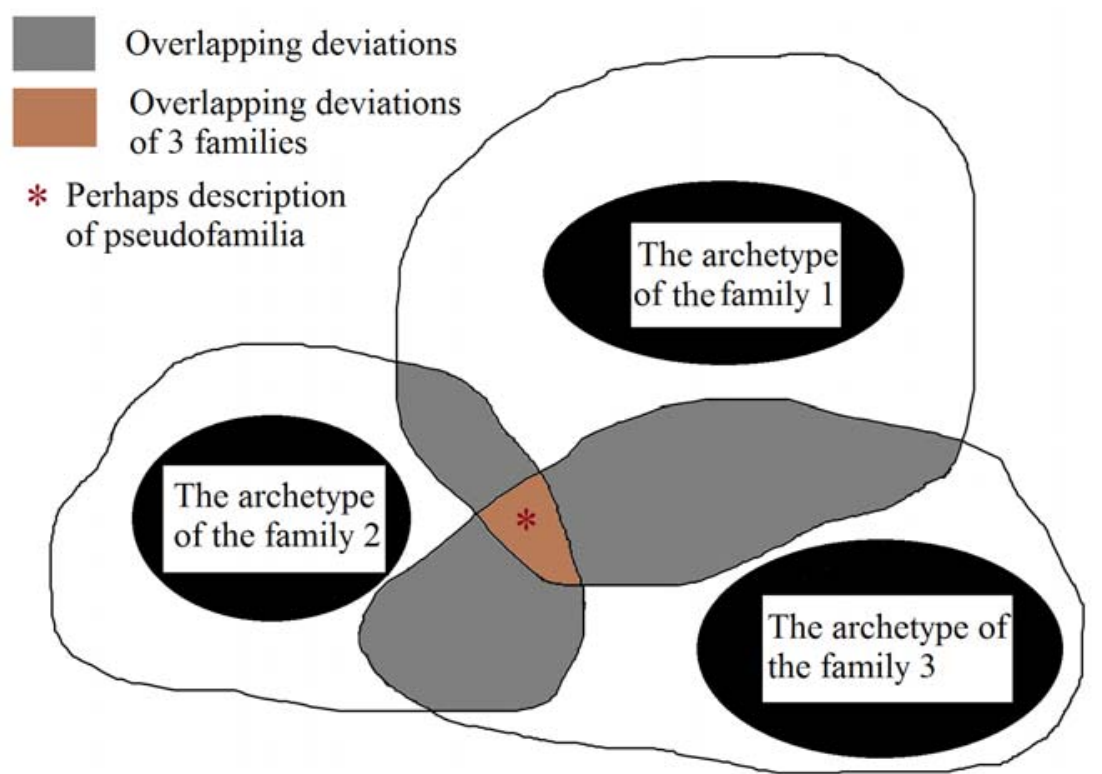

Fig. 2. Interrelationships of the family archetypes of Amphipoda (their "cores") and deviations (aggregates of aberrant forms). Overlapping of deviating taxa (light shading) creates an illusion of the presence of additional families.

Рис. 2. Соотношение архетипов семейств амфипод (их “ядер”) и отклонений (совокупностей аберрантных форм). Перекрывание отклонений (светлая штриховка) создает иллюзию наличия дополнительных семейств. 


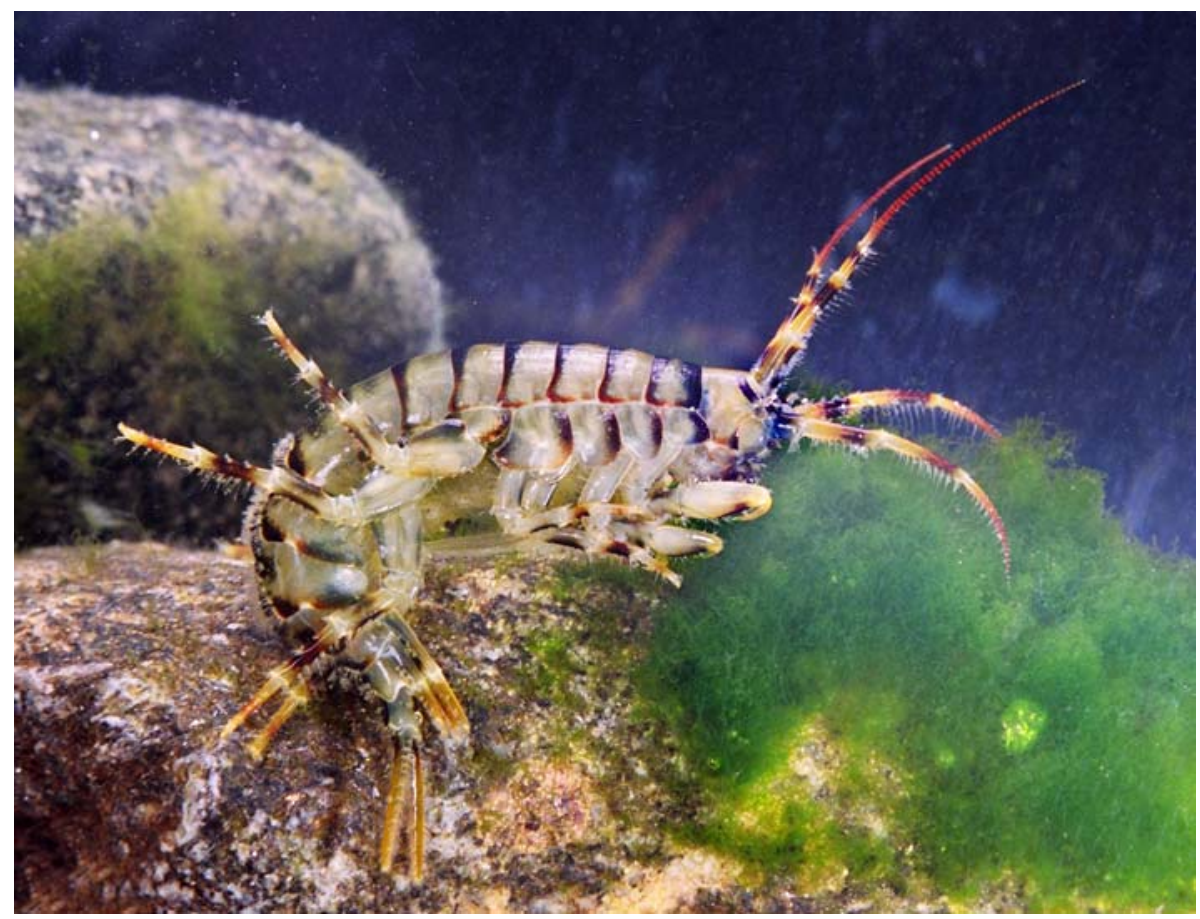

Fig. 3. Eulimnogammarus verrucosus (Gerstfeldt, 1858). Body length up to $36-38 \mathrm{~mm}$. Photo by S.I. Didorenko.

Рис. 3. Eulimnogammarus verrucosus (Gerstfeldt, 1858). Длина тела до 36-38 мм. Фото С.И. Дидоренко.

It is possible to key out archetypes just with clearly separated theses and antitheses in a standard key. It should be remembered that in an intensionally defined taxon, the diagnosis of the archetype corresponds to all included taxa, while in the extensionally taxon it covers only part subordinated taxa that fall within its core.

During the revision of the genus Poekilogammarus, we attempted first to justify a family based on the archetype. It is the family Pallaseidae, which basically includes the amphipods with a somewhat elongated body, a rather thick cuticle and sufficiently large eyes [Tachteew, 1995]. Deviations from the core are numerous. However, many particular deviations motivated Kamaltynov [2001] to raise subgeneric ranks to generic ones and create a series of new genera: Bathygammarus, Onychogammarus, Rostrogammarus, Nyctoporea, Pallaseopsis, Babr, Homalogammarus, Pentagonurus. The same happened after the revision of the genus Plesiogammarus, which clearly demonstrates ecomorphological differentiation, being a taxonomic entity [Takhteev, 1997]. However, it was divided into genera Plesiogammarus, Sentogammarus, Supernogammarus [Kamaltynov, 2001].

Subsequently, we tried to use the archetypic approach in the division of Baikal amphipods into families more reasonably [Takhteev, 2000, 2001]. Six families were established: Gammaridae Leach, 1814, Acanthogammaridae Garjajew, 1901 (with subfamily Garjajewiinae Tachteew, 2000), Pallaseidae Tachteew, 2000, Carinogammaridae Tachteew, 2000, Macrohectopodidae Sowinsky, 1915 and Pachyschesidae Tachteew, 1998 (in the original misspelled Pachyschesiidae).
When presenting diagnoses for such families, the diagnosis of the archetype itself (the most characteristic, "core" features of the taxon) and the characteristic of the observed deviations were presented separately. At the same time, some taxa of the series of families and subfamilies proposed by Kamaltynov [19992009], which, as already discussed, are mostly poorly grounded, can be recognized from the standpoint of this archetypic approach. This is a family of shortlegged amphipods - Micruropodidae Kamaltynov, 1999 (but with a different composition), and subfamilies Parapallaseinae Kamaltynov, 1999 and Hyalellopsinae Kamaltynov, 1999 in Acanthogammaridae. Below we also provide the diagnoses for the archetypes of these taxa. The body length of the species in the illustrations is indicated for the most part according to data provided by Bazikalova [1945, 1962, 1975] with some additions.

\section{Systematic part}

Family Gammaridae Leach, 1914

Type genus: Gammarus Fabricius, 1775

DIAGNOSIS OF ARCHETYPE (Figs 3-5). Body smooth, slender, narrowed laterally, curved towards the midline of the back, absolutely without cuticular armament. At least three of last segments of the body (urosoma) with spines on posterior edge, gathered in paired groups. Head loosely convex, smooth, without elevations on the upper and lateral sides. Rostrum rather short. Eyes dark, flattened (not convex), oval or kidney-shaped (curved), their height always greater than width (generally not less than 1,5 times) and not less than diameter of basal segment of peduncle of antenna 1 . Antenna 1 long, not less than $1 / 2$ of body length. 


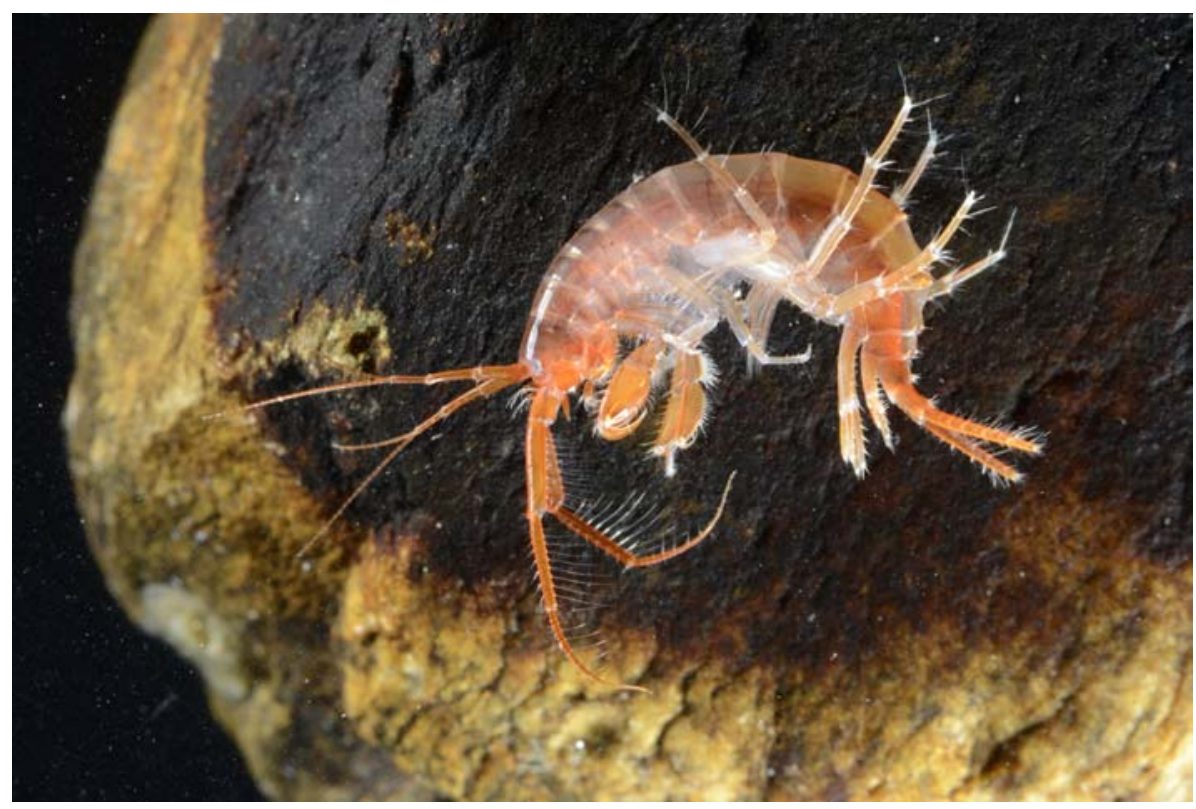

Fig. 4. Corophiomorphus gracilicornis (Bazikalova, 1945). Body length up to $22 \mathrm{~mm}$, or greater. Photo by S.I. Didorenko. Рис. 4. Corophiomorphus gracilicornis (Bazikalova, 1945). Длина тела до 22 мм, возможно, более. Фото С.И. Дидоренко.

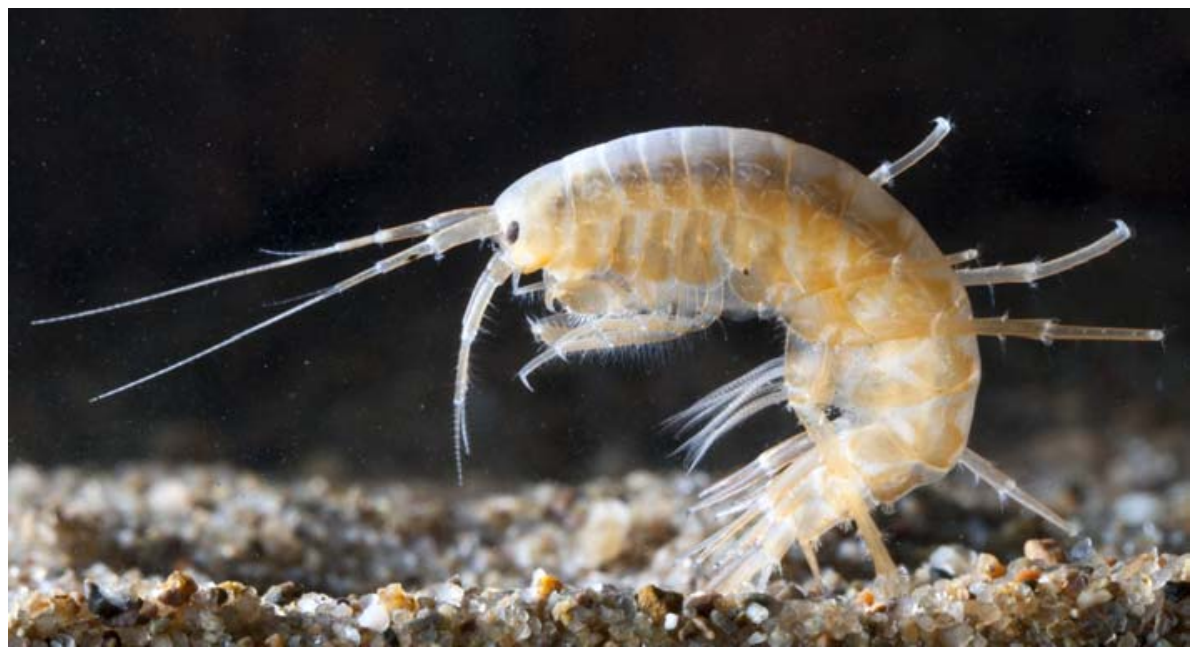

Fig. 5. Odontogammarus calcaratus calcaratus (Dybowsky, 1874). Body length up to $30 \mathrm{~mm}$. Photo by S.I. Didorenko. Рис. 5. Odontogammarus calcaratus calcaratus (Dybowsky, 1874). Длина тела до 30 мм. Фото С.И. Дидоренко.

Accessory flagellum of antenna 1 with no less than 2 segments (one normally developed and one rudimentary), more frequently with 3 or more segments. Outer plate of maxilla 1 with 11 spinules. Coxal plates 1-4 elongated, in 1-3 pairs, round-quadrangular or tongue-shaped. Coxa 1 slightly or substantially shorter than coxa 2 . Bases of pereopods 5-7 with more or less developed tapering down posterior margin, bearing only very short setae. Epimeral plates 2 and 3 broad, with a pronounced, having straight or pointed posteroventral angle. Uropods 1 and 2 with spines. Uropods 3 normally developed, not shortened, not shorter $1 / 8-1 / 6$ of body length. In uropods 3 , outer branch two-segmented, noticeably (not less than a third) longer than inner one, with numerous setae. Telson always deeply split (to or almost to base), branches distally narrowed, having at least one apical spine each.
DEVIATIONS are very diverse and numerous, which suggests the possibility of revision the entire array of genera for belonging to this family. Spines may be present on 6-7 and even on all segments of the body (Abyssogammarus sarmatus echinatus) but may sometimes disappear on the parts of the segments of the urosoma. The family may also contain representatives with the following characters: steep forehead (Ommatogammarus), rounded interantennal lobe (some Eulimnogammarus), stick-shaped bases of pereopods 5-7 (Corophiomorphus), the setae on uropods 1 and 2, appearing independently in different genera. In one case, a higher number of spinules (14) were observed on the outer plate of maxilla 1 (Eulimnogammarus violaceus; see Morino et al. [2000]); in another case, on the contrary, a smaller number ( 8 spinules) is present in Eulimnogammarus cyanoides. In some forms coxa 1 not shorter than 2 , in the 


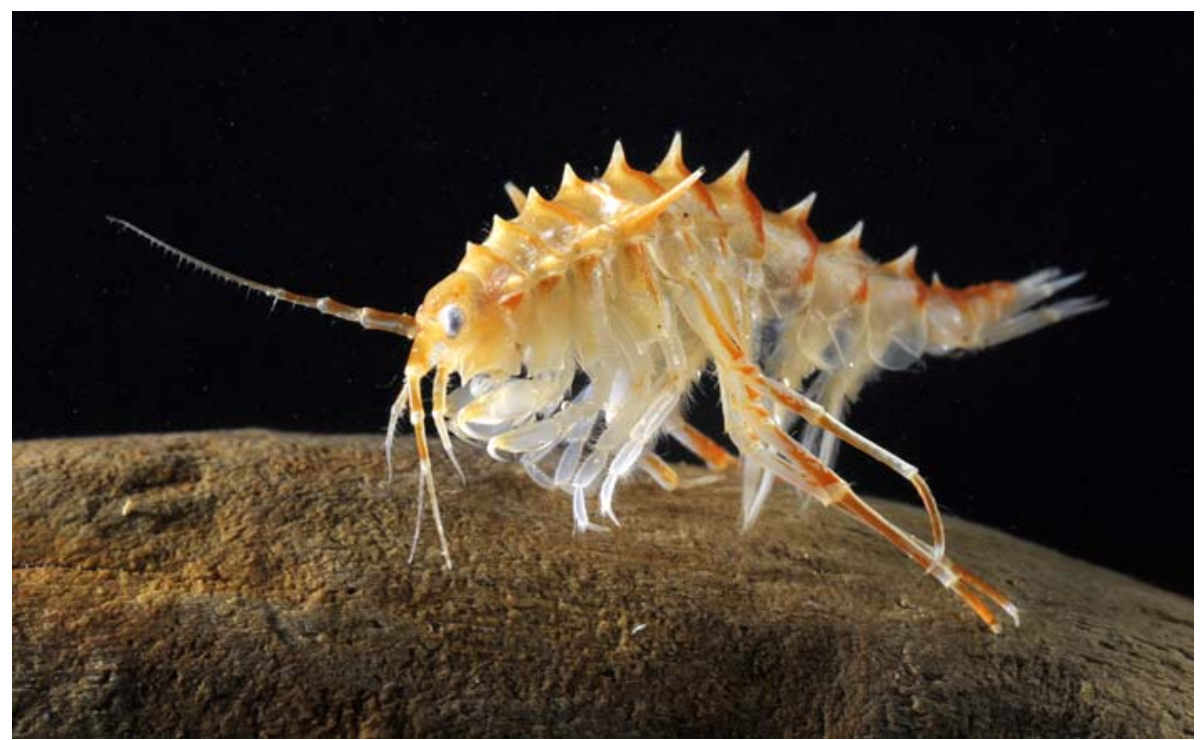

Fig. 6. Acanthogammarus (Acanthogammarus) godlewskii (Dybowsky, 1874). Body length up to 45 mm. Photo by S.I. Didorenko.

Рис. 6. Acanthogammarus (Acanthogammarus) godlewskii (Dybowsky, 1874). Длина тела до 45 мм. Фото С.И. Дидоренко.

other $2^{\text {nd }}$ segment of the outer branch in uropods 3 reduced; sometimes the branches in the latter equal or nearly equal in length. In some deep-water species Eulimnogammarus, i.e. E. aheneus (Dybowsky, 1874), E. macrochirus (Bazikalova, 1945), the posterior side of bases of pereopods 5-7 can bear setae of moderate length. In some species adults have a reduced $2^{\text {nd }}$ segment of the outer branch of the uropods 3 (Eulimnogammarus marituji Bazikalova, 1945).

COMPOSITION. The following Baikal genera are included in the family: Abyssogammarus Sowinsky, 1915; Bazikalovia Tachteew, 2000; Corophiomorphus Bazikalova, 1945; Eulimnogammarus Bazikalova, 1945 with subgenera Philolimnogammarus Bazikalova, 1945 and Eurybiogammarus Bazikalova, 1945; Fluviogammarus Dorogostajsky, 1916 (the genus endemic to the upper basin of Angara river); Heterogammarus Stebbing, 1899; Odontogammarus Stebbing, 1899; Ommatogammarus Stebbing, 1899.

The genus Gammarus is represented in the region only by a widespread euryhaline species G. lacustris occurring in the water bodies surrounding Lake Baikal: the lagoons ("sors"), in the mineralized (sodium chloride) springs of the Predbaikal'skaya foothill depression [Takhteev et al., 2017]. It is never found in the Lake Baikal proper. In addition, Gammarus dabanus Tachteew et Mekhanikova, 2000 is endemic for the mountain ridge Khamar-Daban, which borders the southern part of Baikal Lake where it inhabits cold-water brooks, small spring streams and rivularies into the Lake [Takhteev, Mekhanikova, 2000].

REMARKS. One of the Gammarus species, G. roeselii Gervais, 1835 from Europe [Karaman, Pinkster, 1977], is characterized by the presence of outgrowths of the posterior edges of the metasoma segments ("pleosomal spines"), similar to those in the endemic Baikal Macrohectopodidae (see below).

Family Acanthogammaridae Garjajew, 1901

Type genus: Acanthogammarus Stebbing, 1899.

DIAGNOSIS OF ARCHETYPE (Figs 6-9). Large and medium-sized amphipods with thick integuments and armoured cuticle (teeths, keels, extensive swellings). Teeth of the median row are placed vertically or only slightly tilted backwards. The body usually enlarged. Lateral rows of elevations usually weaker than those of the medial row or absent. Eyes small or medium-size, convex, dark, kidneyshaped. Calceoli on antennae absent. Gnathopods with large almond-shaped propodus. Pereiopods 5-7 long, with slender bases, which posterior edges lack setae. Epimeral plates with blunt or rounded posteroventral corners.

DEVIATIONS. There are small and even dwarf forms (in the genera Hyalellopsis, Plesiogammarus, Koshovia). The armament is in some cases is reduced to low tubercles and swellings (the same genera), or developed only in marginal rows (Burchania), or median elevations are expressed at only part of the segments (Carinurus, Coniurus); sometimes in certain segments lateral rows are developed stronger than medial ones (Propachygammarus). In deep-water forms the eyes are white or pink (Garjajewia, Koshovia, Paragarjajewia, most species of Plesiogammarus, some Acanthogammarus spp., etc.). The antennae can be shortened (Brandtia s.str., Hyalellopsis). Pereopods may be short, with wide bases (Hyalellopsis).

Subfamily Acanthogammarinae Garjajew, 1901

Type genus: Acanthogammarus Stebbing, 1899.

DIAGNOSIS OF ARCHETYPE (Figs 10-12). Large and medium sized animals. Cuticle strong. Body widened anteriorly. Median row of elevations in the form of welldeveloped teeths or keels on all or on part of the segments, the lateral rows are poorly developed or absent, the marginal rows in the form of strong teeths, keels or strongly expressed swollens. Eyes dark, convex. Antennae 1 to $2 / 3$ of the length of the body or much shorter. Coxal plates 1-4 large, high, 4th pair often with a tooth or a hillock. Epimeral plates without long setae.

DEVIATIONS. See diagnosis of the family.

COMPOSITION. Acanthogammarus Stebbing, 1899 with subgenus Brachyuropus Stebbing, 1899; Brandtia Bate, 1862 with subgenus Dorogostajskia Kamaltynov, 2001; Burchania Tachteew, 2000; Carinurus Sowinsky, 1915; Coniurus Sowinsky, 1915; Propachygammarus Bazikalova, 1945. 


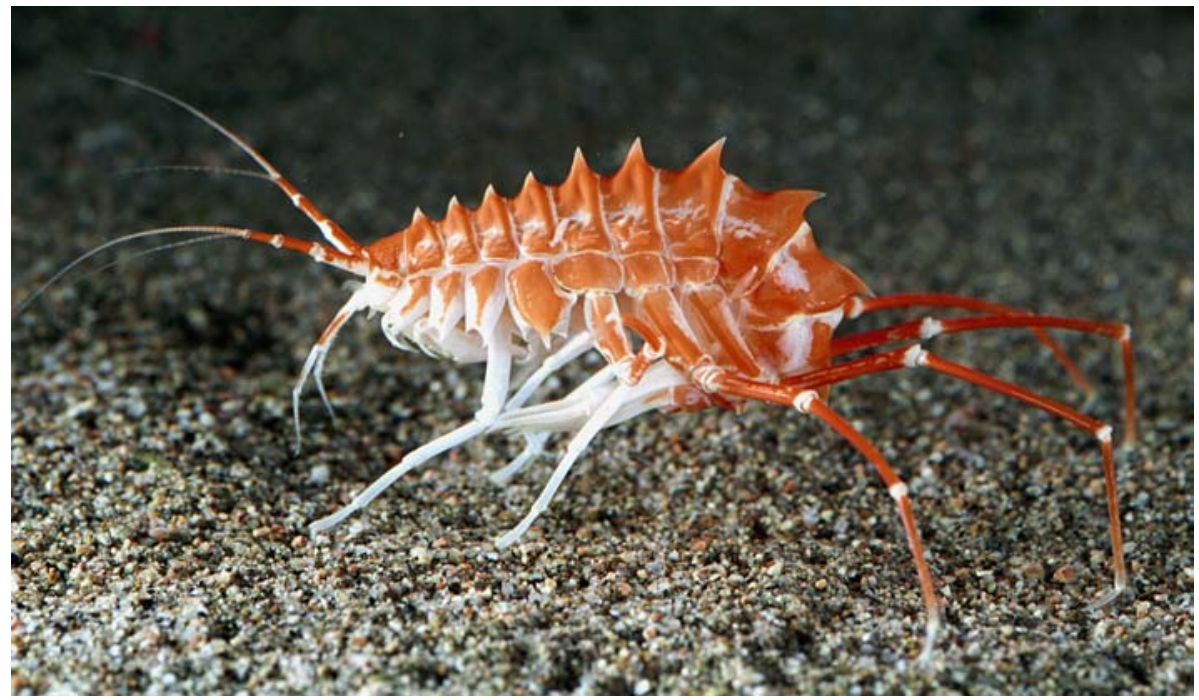

Fig. 7. Acanthogammarus (Brachyuropus) reichertii (Dybowsky, 1874). Body length up to $38 \mathrm{~mm}$. Photo by S.I. Didorenko. Pис. 7. Acanthogammarus (Brachyuropus) reichertii (Dybowsky, 1874). Длина тела до 38 мм. Фото С.И. Дидоренко.

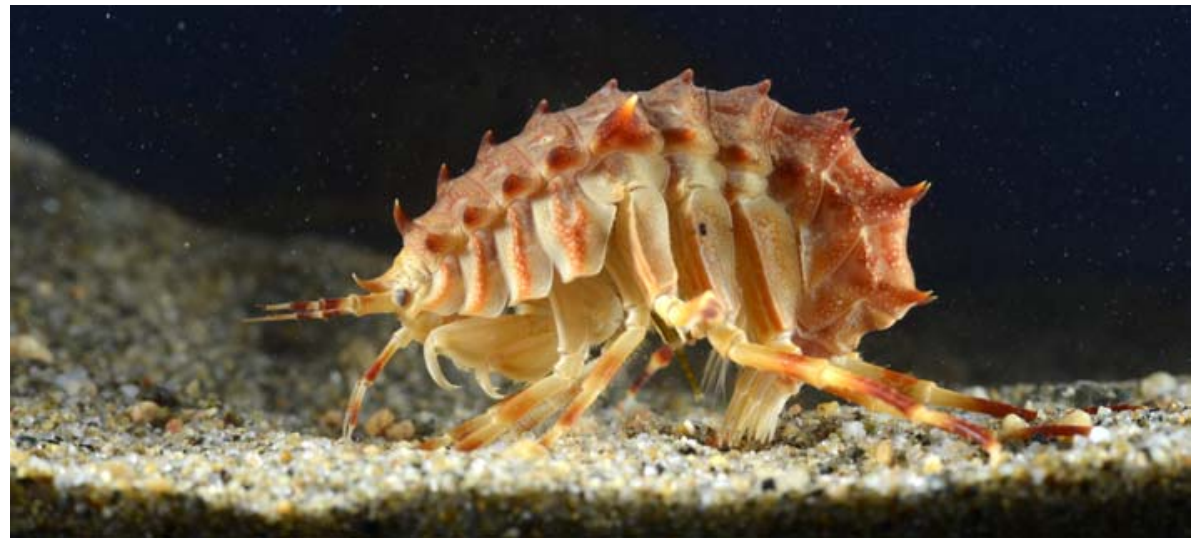

Fig. 8. Propachygammarus maximus (Garjajew, 1901). Body length up to $67 \mathrm{~mm}$. Photo by S.I. Didorenko. Рис. 8. Propachygammarus maximus (Garjajew, 1901). Длина тела до 67 мм. Фото С.И. Дидоренко.

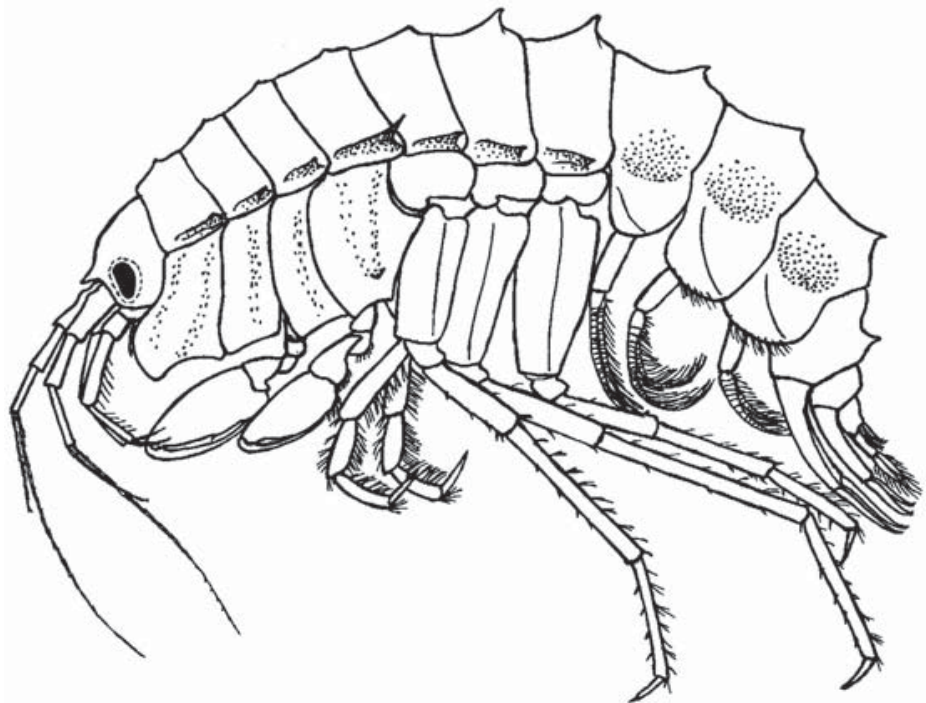

Fig. 9. Acanthogammarus (Acanthogammarus) maculosus Dorogostaisky, 1930. Specimen with length $51.5 \mathrm{~mm}$. Maximum length 56 mm. Drawing by V.V. Takhteev.

Рис. 9. Acanthogammarus (Acanthogammarus) maculosus Dorogostaisky, 1930. Экземпляр с длиной тела 51,5 мм. Максимальная длина 56 мм. Рисунок В.В. Тахтеева. 


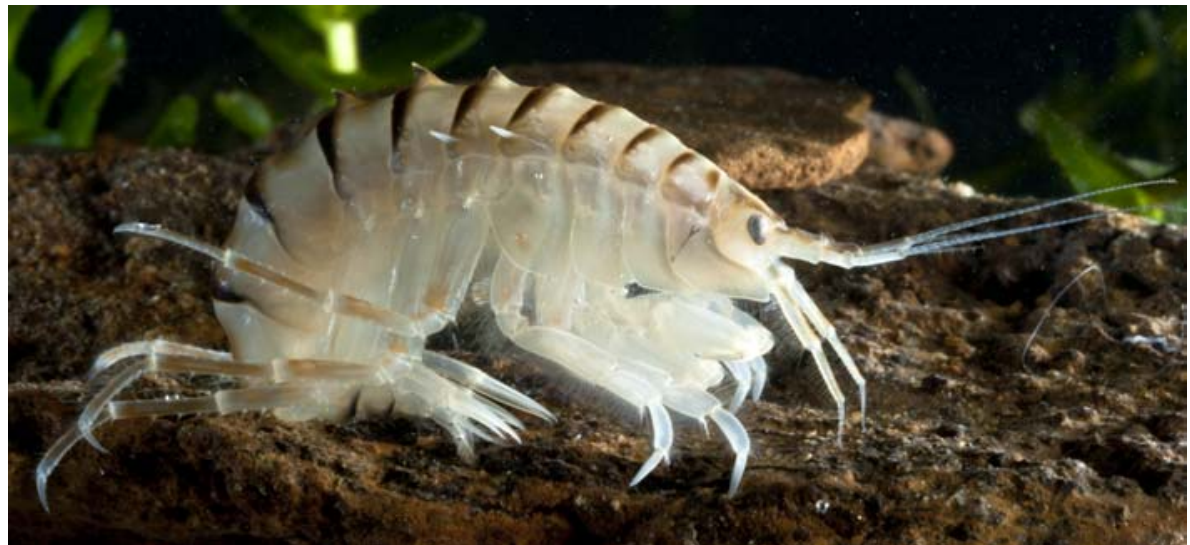

Fig. 10. Acanthogammarus (Acanthogammarus) brevispinus Dorogostaisky, 1922. Local endemic in area near the Delta of the Selenga River. Body length up to $36 \mathrm{~mm}$. Photo by S.I. Didorenko.

Рис. 10. Acanthogammarus (Acanthogammarus) brevispinus Dorogostaisky, 1922. Локальный эндемик придельтового участка $\mathrm{p}$. Селенга. Длина тела до 36 мм. Фото С.И. Дидоренко.

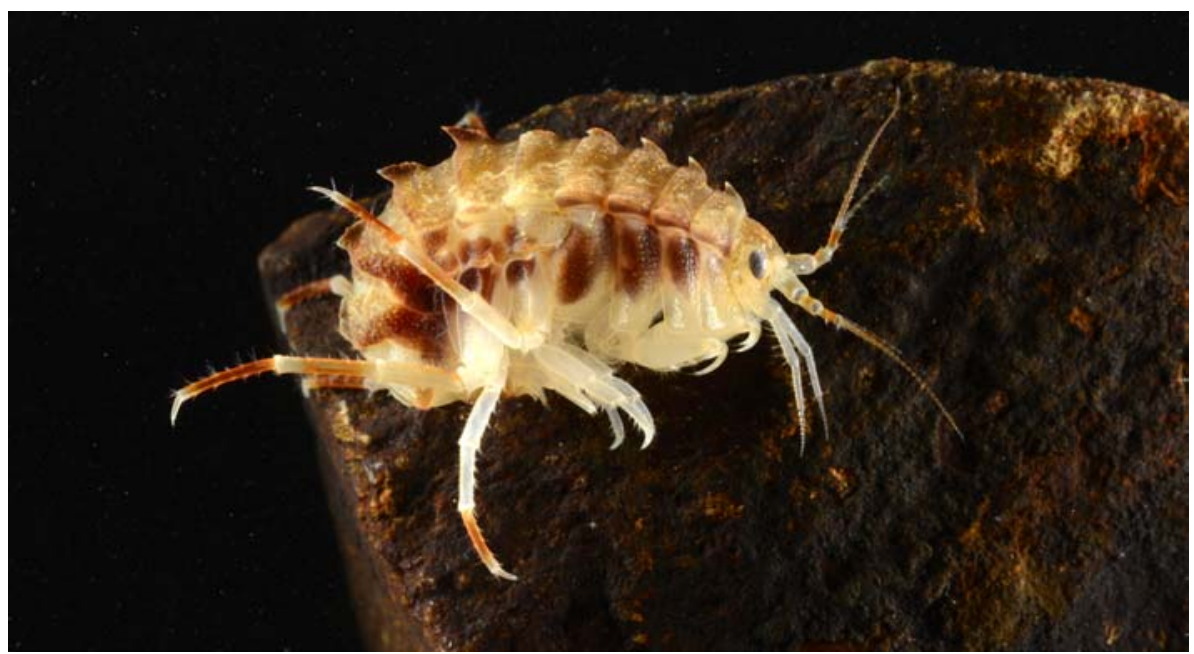

Fig. 11. Acanthogammarus (Brachyuropus) korotneffii (Garjajew, 1901). Body length up to $26 \mathrm{~mm}$. It is confined to the area of the Ushkany Islands. Photo by S.I. Didorenko.

Pис. 11. Acanthogammarus (Brachyuropus) korotneffii (Garjajew, 1901). Длина тела до 26 мм. Распространение вида приурочено к району Ушканьих островов. Фото С.И. Дидоренко.

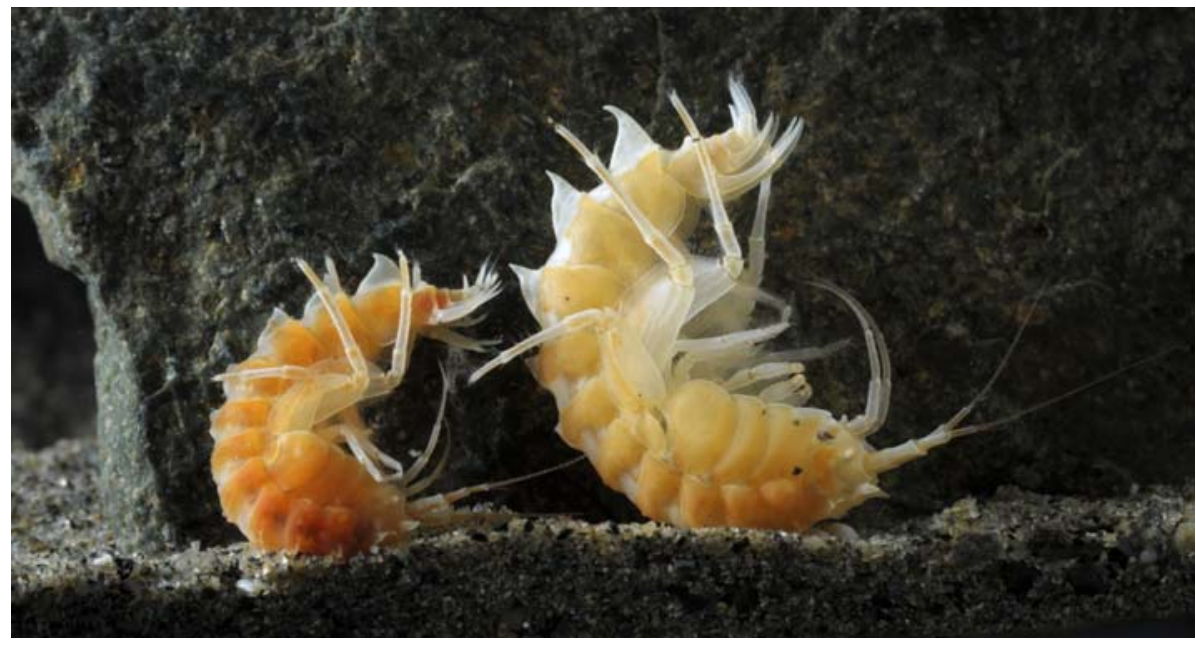

Fig. 12. Carinurus reissnerii (Dybowsky, 1874). Body length up to $16 \mathrm{~mm}$. Photo by S.I. Didorenko.

Рис. 12. Carinurus reissnerii (Dybowsky, 1874). Длина тела до 16 мм. Фото С.И. Дидоренко. 


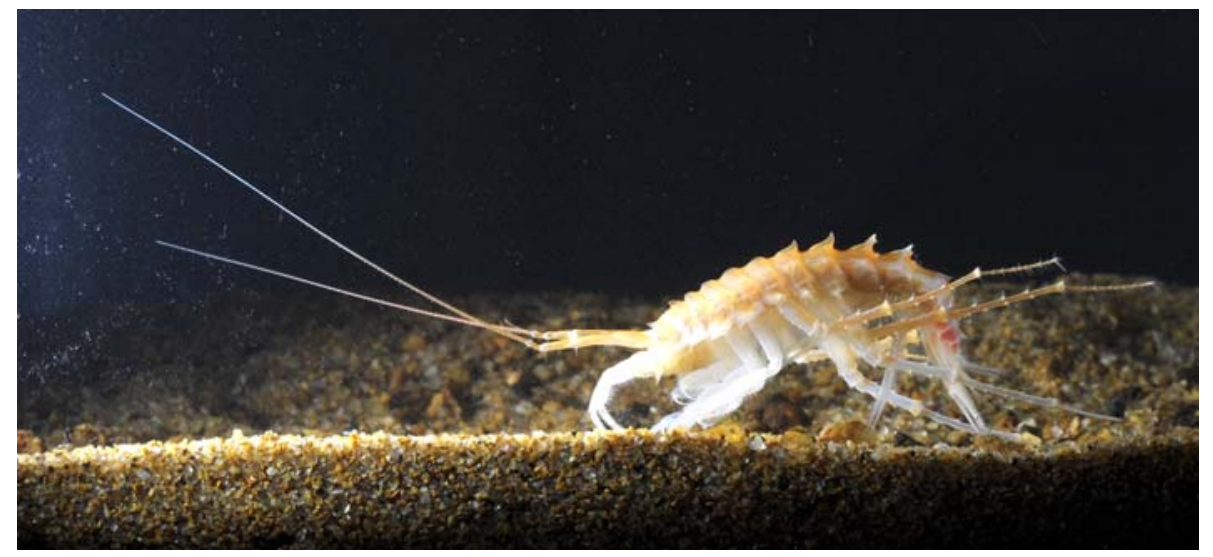

Fig. 13. Garjajewia cabanisii cabanisii (Dybowsky, 1874). Body length up to $80 \mathrm{~mm}$. Photo by S.I. Didorenko. Рис. 13. Garjajewia cabanisii cabanisii (Dybowsky, 1874). Длина тела до 80 мм. Фото С.И. Дидоренко.

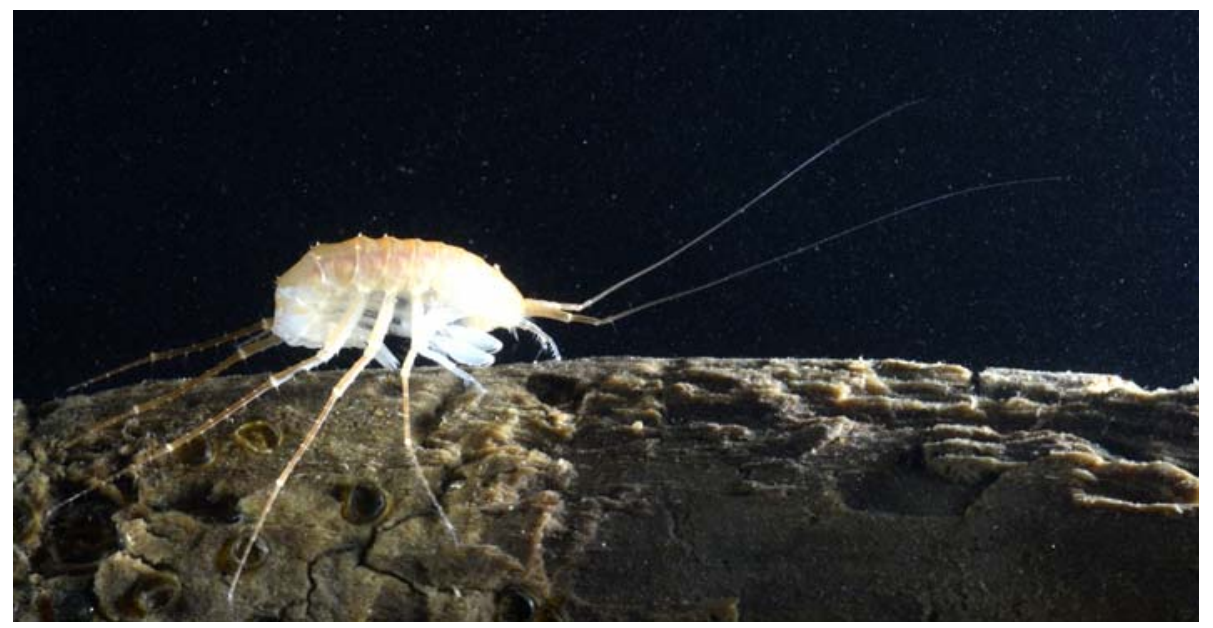

Fig. 14. Plesiogammarus zienkowiczii (Dybowsky, 1874). Body length up to $35 \mathrm{~mm}$ (Takhteev, 1997). Photo by S.I. Didorenko. Рис. 14. Plesiogammarus zienkowiczii (Dybowsky, 1874). Длина тела до 35 мм (Takhteev, 1997). Фото С.И. Дидоренко.

Subfamily Garjajewiinae Tachteew, 2000

Type genus: Garjajewia Sowinsky, 1915.

DIAGNOSIS OF ARCHETYPE (Figs 13, 14). Large amphipods. Body elongate, slightly widened in anteriorly. Middle row of elevations in form of keels with secondary spines. Marginal rows in form of vague swellings, lateral rows absent. Head without outgrowths on lateral surface, often with developed interantennal lobes. Eyes white or pink in living specimens, discolored in fixed ones. Antennae 1 not shorter than half length of body (often very long), basal segment of their stem is long, narrowed distally, $3^{\text {rd }}$ segment shorter than $2^{\text {nd }}$ one. Coxal plates 1-4 small, short, 4th pair not armoured on outer side. Bases of pereopods 5-7 narrow (stick-shaped), "wing" at posterior edge not expressed or only weakly developed; claws weak. In uropod 3 branches with dense setae, outer slightly longer than inner or both of equal length. Telson of moderate length.

DEVIATIONS. The medial row of elevations in some species is absent for the second time. Interantennal lobes can be triangular, pointed (Garjajewia, Plesiogammarus zienkowiczii) or evenly rounded (Paragarjajewia, most Plesiogammarus), and eyes are rarely dark-pigmented (Plesiogammarus longicornis). Epimeral plates in some cases with bundles of rather long bristles, in others bristles are lacking. The most deviated
Plesiogammarus (P. brevis with subspecies, P. timoshkini) have much shortened uropods 3 , which outer branch is twice as long as the inner one, both bearing only a few setae.

COMPOSITION. Garjajewia Sowinsky, 1915; Koshovia Bazikalova, 1975; Paragarjajewia Bazikalova, 1945; Plesiogammarus Stebbing, 1899.

Subfamily Hyalellopsinae Kamaltynov, 1999

Type genus: Hyalellopsis Stebbing, 1899.

DIAGNOSIS OF ARCHETYPE (Figs 15-17). Small (Hyalellopsis) or medium-sized (Boeckaxelia, Dorogammarus) amphipods. Body robust, strongly widened, not more than 2-3 times as long as wide, often with weak or moderately developed specific armament (tubercles, transverse ribs, longitudinal keels), rarely smooth; with very thick cuticle. Eyes always convex. Antennae short, significantly shorter than $1 / 2$ body length. Accessory flagellum of antenna 1 consists of 1 to 4 segments. Coxal plates very wide. Pereopods short, their bases considerably expanded posteriorly. Uropods 1 and 2 rather poorly developed, in most cases, devoid of setae and bear only spines. Uropods 3 very short, usually less than $10 \%$ body length, and often rudimentary: branches only in form of tubercles, either one of them or both practically absent. 


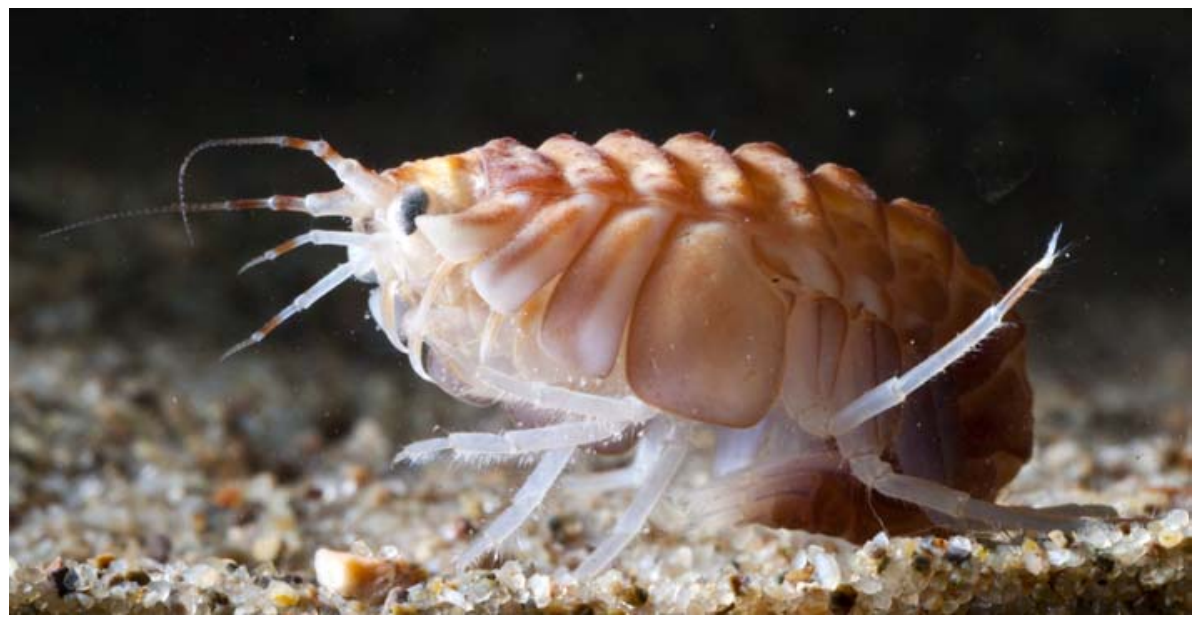

Fig. 15. Hyalellopsis (Boeckaxelia) carpenterii carpenterii (Dybowsky, 1874). Body length up to $30 \mathrm{~mm}$. Photo by S.I. Didorenko. Рис. 15. Hyalellopsis (Boeckaxelia) carpenterii carpenterii (Dybowsky, 1874). Длина тела до 30 мм. Фото С.И. Дидоренко.

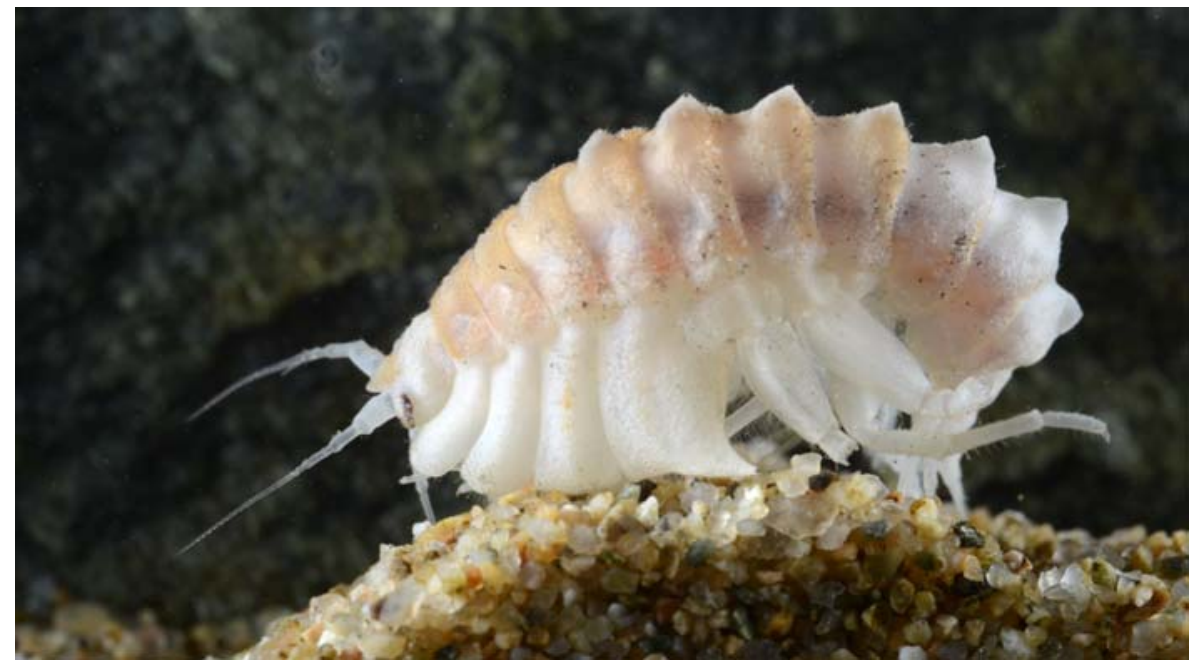

Fig. 16. Hyalellopsis (Boeckaxelia) rubra (Garjajew, 1901). Body length up to $34 \mathrm{~mm}$. Photo by S.I. Didorenko. Pис. 16. Hyalellopsis (Boeckaxelia) rubra (Garjajew, 1901). Длина тела до 34 мм. Фото С.И. Дидоренко.

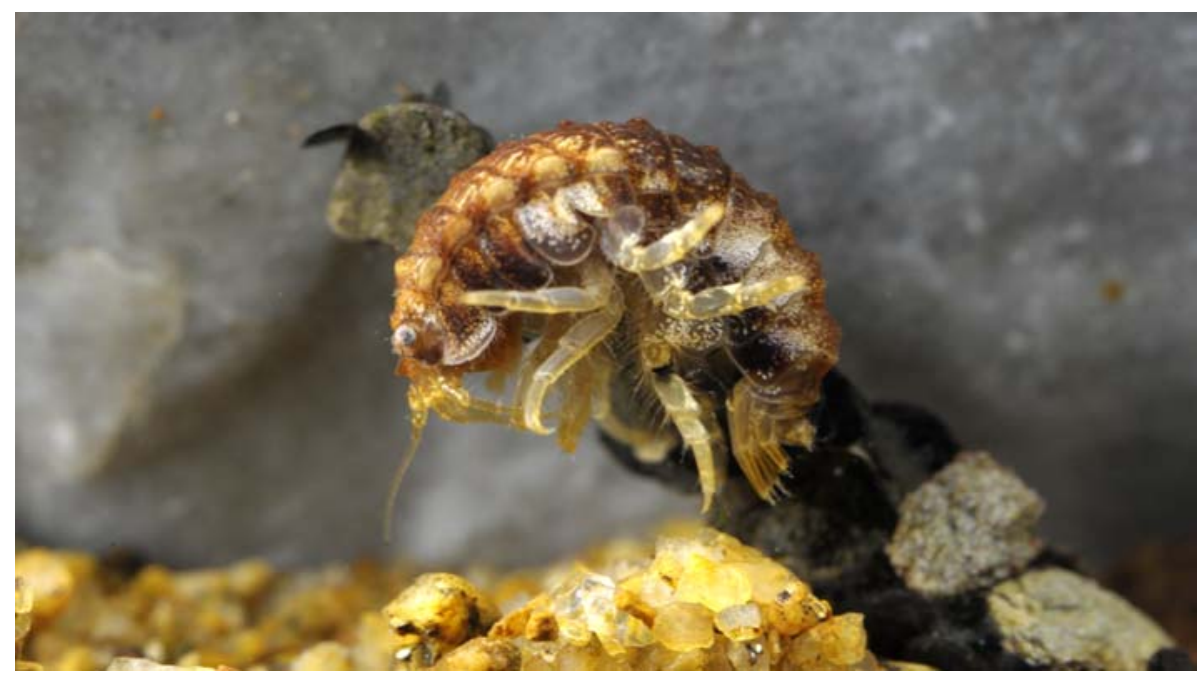

Fig. 17. Hyalellopsis (Hyalellopsis) sp. Undescribed species from the Strait Olkhonskiye Vorota. Photo by S.I. Didorenko. Рис. 17. Hyalellopsis (Hyalellopsis) sp. Неописанный вид из пролива Ольхонские Ворота. Фото С.И. Дидоренко. 


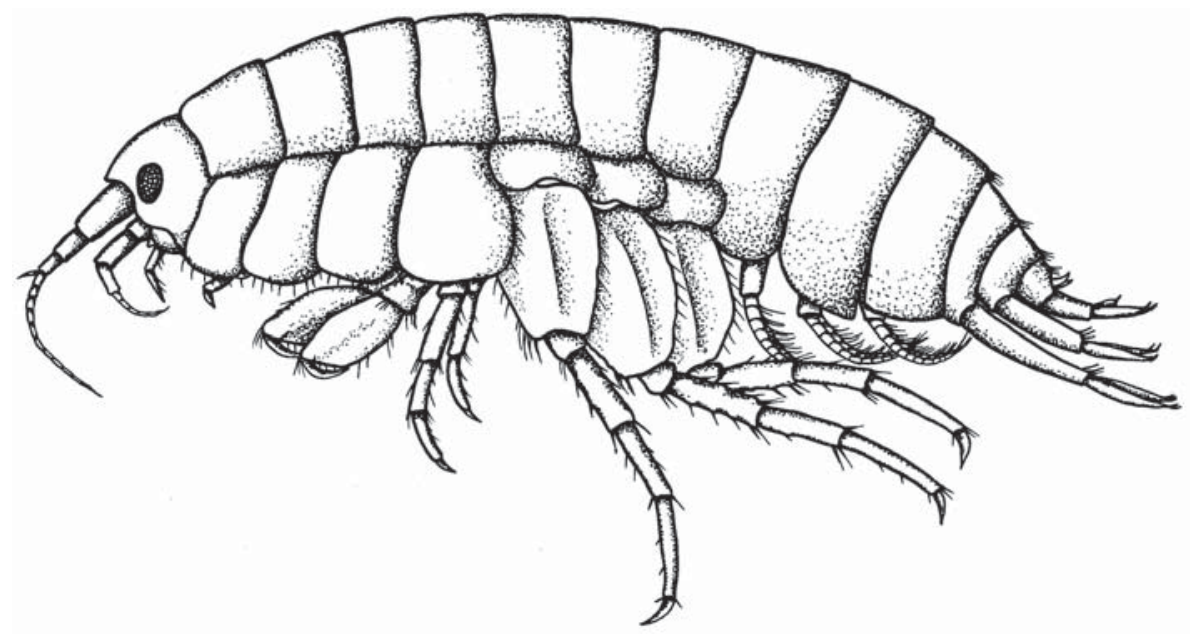

Fig. 18. Micruropus galasii Bazikalova, 1962. Body length up to $6 \mathrm{~mm}$. Drawing by I.V. Golenkova. Рис. 18. Micruropus galasii Bazikalova, 1962. Длина тела до 6 мм. Рисунок И.В. Голенковой.

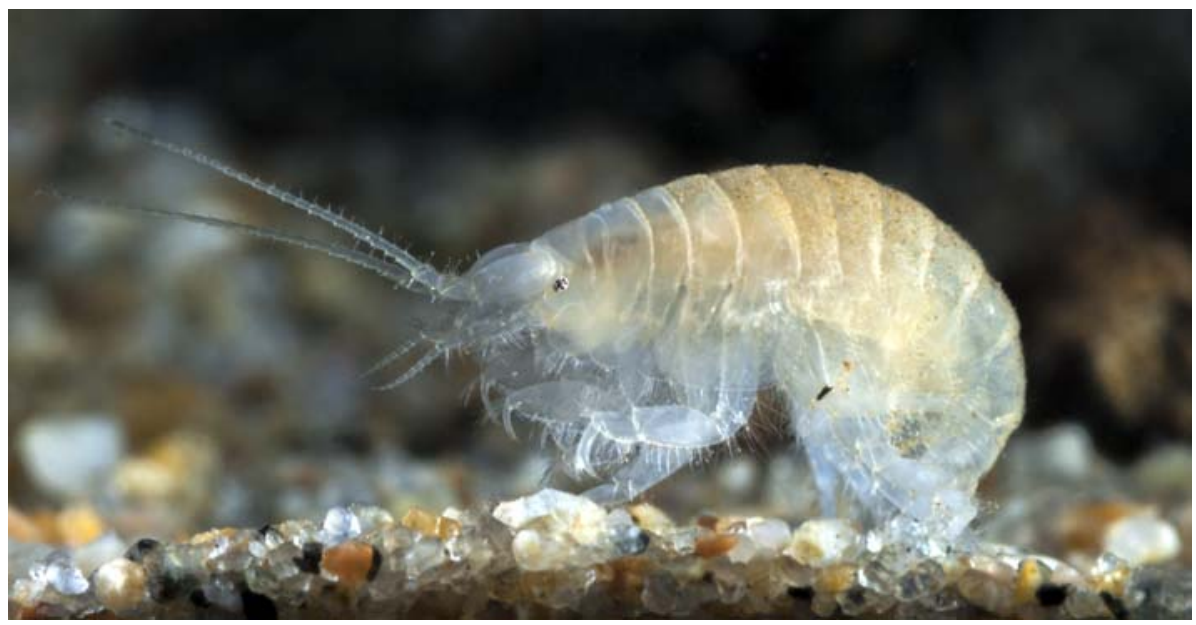

Fig. 19. Crypturopus inflatus (Dybowsky, 1874). Body length up to $16-18 \mathrm{~mm}$. Photo by S.I. Didorenko.

Pис. 19. Crypturopus inflatus (Dybowsky, 1874). Длина тела до 16-18 мм. Фото С.И. Дидоренко.

DEVIATIONS. Segments of urosoma 1 and 2 can be fused: H. (Gammarosphaera) insularis (Bazikalova, 1936). Uropod 3 can have a normal morphology with two visible branches (subgenus Boeckaxelia), although never long.

COMPOSITION. Hyalellopsis Stebbing, 1899 with subgenera Boeckaxelia Bazikalova, 1948, Dorogammarus Bazikalova, 1945, and Gammarosphaera Bazikalova, 1945; Cheirogammarus Sowinsky, 1915.

REMARKS. The status of the monotypic genus Cheirogammarus is unclear. Cheirogammarus inflatus Sowinsky, 1915 was described upon a single holotype specimen, which is deposited in the Zoological Institute of National Academy of Science of Ukraine and is in a very poor condition, it is difficult to accurately determine its place in the system. Another specimen was identified by Dorogostajsky [1936] from the Barguzin Bay, but this material appeared to be lost.

Family Micruropodidae Kamaltynov, 1999

Type genus: Micruropus Stebbing, 1899.

DIAGNOSIS OF ARCHETYPE (Figs 18, 19). Small animals, often not longer than $10 \mathrm{~mm}$. Body compact, not long, without rows of elevations (including median ones).
Spines on metasoma segments never present. Urosoma without strongly developed spines, only with setae or bare, or with few small spinules (part of Micruropus species). Head integument smooth. Antennae short, considerably shorter than body. Antennae 1 usually slightly longer than antennae 2. Accessory flagellum one-segmented, rarely with a rudimentary second segment. Propodi of gnathopods slender. Most of body appendages with abundant setae (species characterized mostly by burrowing way of life). Bases of pereopods 5-7 usually short, in various degree broadened, with more or less long setae on posterior margin. Uropods 3 shortened, sometimes considerably (but not reduced). Telson short, divided to base or nearly so.

DEVIATIONS. Uropod 3 can be rather well developed, emarginated with plumose setae and serve for active swimming, i.e. in Micruropus wohlii wohlii (Dybowsky, 1874), M. wohlii platycercus (Dybowsky, 1874). Species of the genus Crypturopus have a thick body, a wide head, its width may even exceed the height. The genus Baikalogammarus is characterized by sexual dimorphism in body size and a bent downwards under the head, long antennal cone. In Micruropus minutus (Sowinsky, 1915) pereopods have subchaelate 


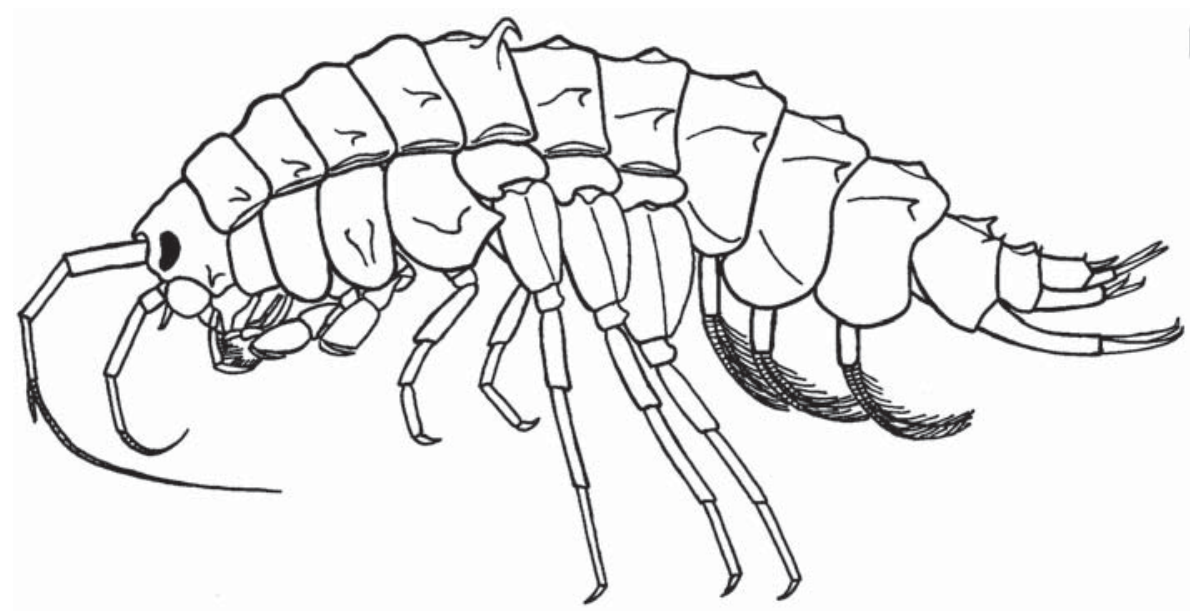

Fig. 20. Pallasea (Pallasea) cancellus cancellus (Pallas, 1767). Body length up to $65 \mathrm{~mm}$. Drawing by V.V. Takhteev. Рис. 20. Pallasea (Pallasea) cancellus cancellus (Pallas, 1767). Длина тела до 65 мм. Рисунок В.В. Тахтеева.

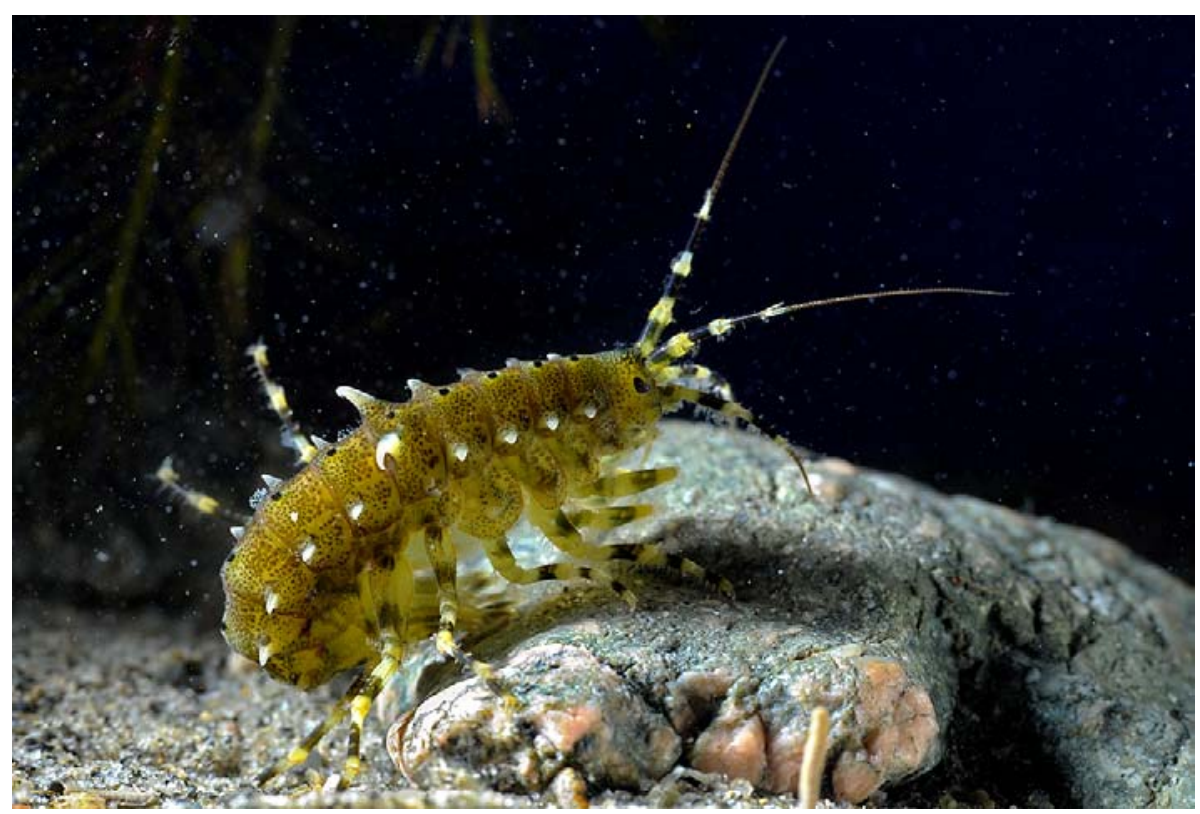

Fig. 21. Pallasea (Pallasea) cancellus, immature specimen. Photo by S.I. Didorenko.

Рис. 21. Pallasea (Pallasea) cancellus, неполовозрелый зкземпляр. Фото С.И. Дидоренко.

structure (much like Pachyschesidae). Eyes are usually rather large, dark, but can be devoid of pigment: Homocerisca spp., Micruropus parvulus Bazikalova, 1945, or may look like dots: Crypturopus inflatus (Dybowsky, 1874) (Fig. 19), Micruropus semenovi Bazikalova, 1945, M. ciliodorsalis Sowinsky, 1915.

COMPOSITION. Micruropus Stebbing, 1899; Crypturopus Sowinsky, 1915; Homocerisca Bazikalova, 1945; Baikalogammarus Stebbing, 1899.

REMARKS. We accept the composition of the family in the sense of Stebbing's [Stebbing, 1899] concept for the established by him genus Micruropus (including both $\mathrm{Mi}$ cruropus and Crypturopus of the present classification), with the addition of later described Homocerisca, close to Crypturopus. All gammarids with tubercles, particularly with the median row of elevations, included in Micruropodidae by Kamaltynov, in fact, have to be treated as Carinogammaridae (i.e. genera Echiuropus, Pseudomicruropus and
Gmelinoides). Gmelinoides fasciatus Stebbing, 1899 may constitute an exception could be, because in the molecular phylogenetic reconstruction this species falls in the same clade as Micruropus wohlii (D.A. Sidorov, pers. comm.). These species are also similar in behavior (burying in the ground, forming huge migration accumulations). However, this can be seen as evidence of the common origin of the two families and, at the same time, of a significant age of the two mentioned species. From the constructive morphology standpoint, the presence of median tubercles on several segments of the body is a character of the archetype of the Carinogammaridae, where we place G. fasciatus.

Family Pallaseidae Tachteew, 2000 (Pallaseidae Tachteew, 1995 is nomen nudum)

Type genus: Pallasea Bate, 1862.

DIAGNOSIS OF ARCHETYPE (Figs 20, 21). Amphipods of medium or relatively large size. Median row of 


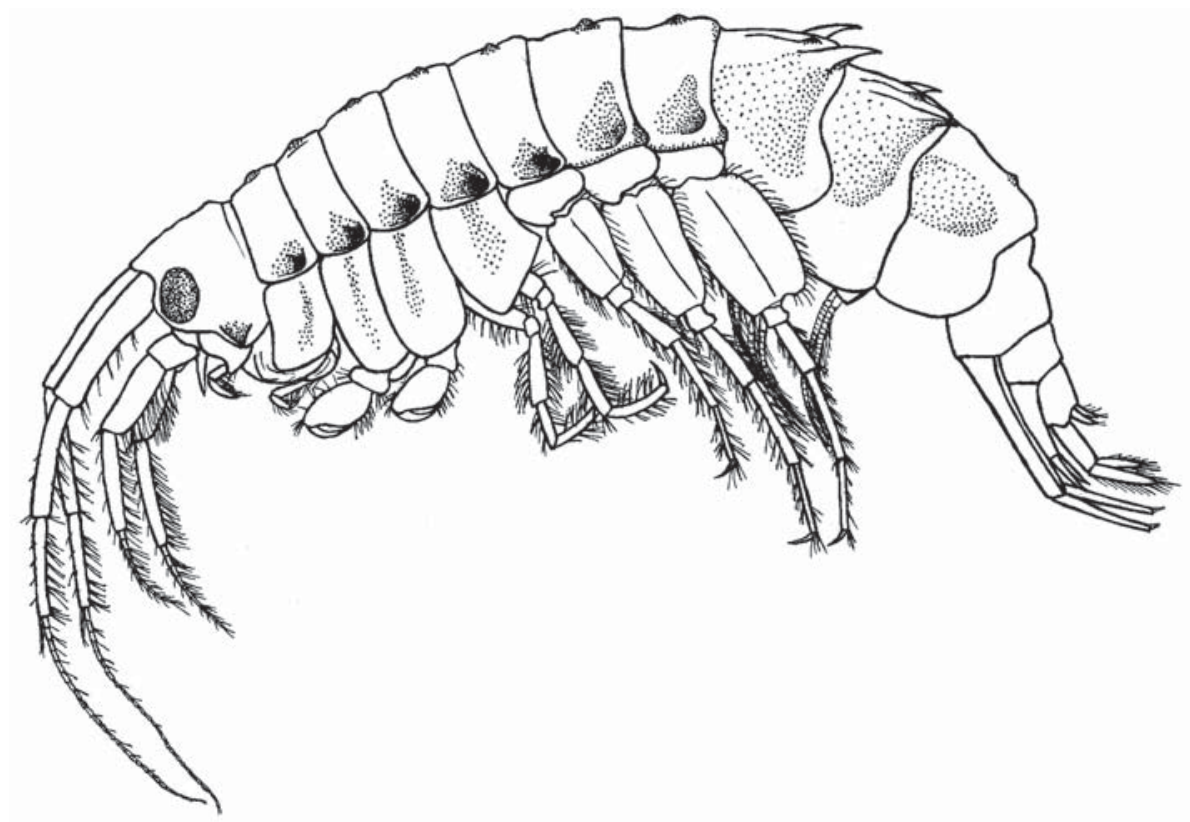

Fig. 22. Pallasea (Pallasea) kesslerii (Dybowsky, 1874). Body length up to $33 \mathrm{~mm}$. Drawing by V.V. Takhteev. Рис. 22. Pallasea (Pallasea) kesslerii (Dybowsky, 1874). Длина тела до 33 мм. Рисунок В.В. Тахтеева.

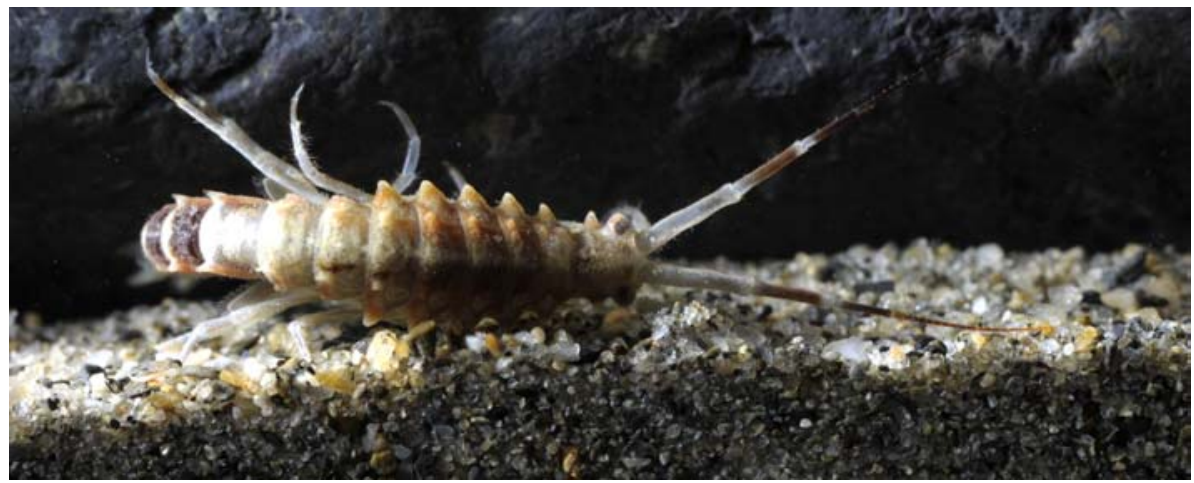

Fig. 23. Pallasea (Pallasea) kesslerii (Dybowsky, 1874). Armature from dorsal side. The teeths on the metasome segments are directed backwards. Photo by S.I. Didorenko.

Рис. 23. Pallasea (Pallasea) kesslerii (Dybowsky, 1874). Вид вооружения с дорсальной стороны. Зубцы сегментов метасомы направлены назад. Фото С.И. Дидоренко.

elevations absent or poorly developed, always much weaker than lateral and (or) marginal rows. Eyes always pigmented, in a fixed state, convex, rounded or oblong. Antennae 1 about half length of body or longer, and about twice length of antennae 2. Calceoli always absent. Bases of pereopods 5-7 moderately broad, tapering downwards. Epimeral plates wide. Uropod 3 well developed, outer branch always long, with densely developed setae.

REMARKS. The name was first proposed in Tachteew [1995]; unfortunately, in this paper only the genera included in the family were listed but no diagnosis provided. This was done only 5 years later and since that time the name Pallaseidae became available [Takhteev, 2000].

Subfamily Pallaseinae Tachteew, 2000

Type genus: Pallasea Bate, 1862.

DIAGNOSIS OF ARCHETYPE (Figs 22-25). Amphipods of medium size or larger. Median row of elevations is poorly developed, in form of bumps, lateral and/or marginal rows in the form of teeths or noticeable keels, directed posteriorly or postero-laterally. Eyes dark, round or ovoid, considerably convex. Coxal plates quite high, with smoothly rounded corners. Propodus of gnathopods large (Pallasea cancellus) or small (Metapallasea, some Poekilogammarus). Complete set of body armature in Pallasea; in other genera median and lateral rows reduced, marginal ones only in form of tubercles (Fig. 26). Rostrum can reach considerable length (subgenera Rostrogammarus and Variogammarus in genus Poekilogammarus). Epimeral plates with smoothly rounded lower and posterior (Pallasea) or with pointed (Poekilogammarus) corners. Branches of uropods 3 may differ several times in length (Pallasea grubii, Metapallasea).

DEVIATIONS. In Pallasea baikali Stebbing, 1899 (subgenus $B a b r$ ) only marginal rows of elevations are developed. Eyes large (many Poekilogammarus), in some cases narrow, flat and partly depigmented (subgenus Bathygammarus in Poekilogammarus). Although pigmentation never completely disappear even in preserved specimens. In Meta- 


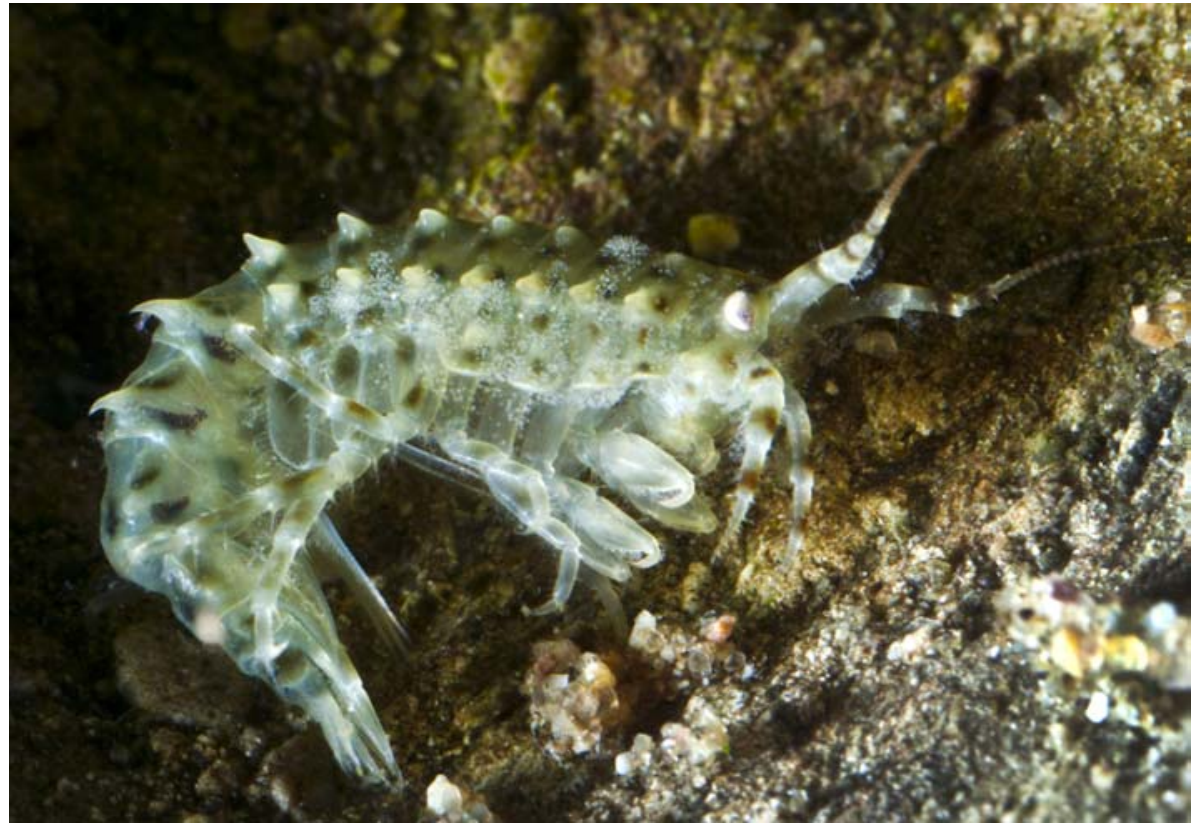

Fig. 24. Pallasea (Pallasea) cancelloides (Gerstfeldt, 1858). Body length up to $25 \mathrm{~mm}$. The teeths on the metasome segments are directed back and to the sides. Photo by S.I. Didorenko.

Рис. 24. Pallasea (Pallasea) cancelloides (Gerstfeldt, 1858). Длина тела до 25 мм. Зубцы сегментов метасомы направлены назад и в стороны. Фото С.И. Дидоренко.

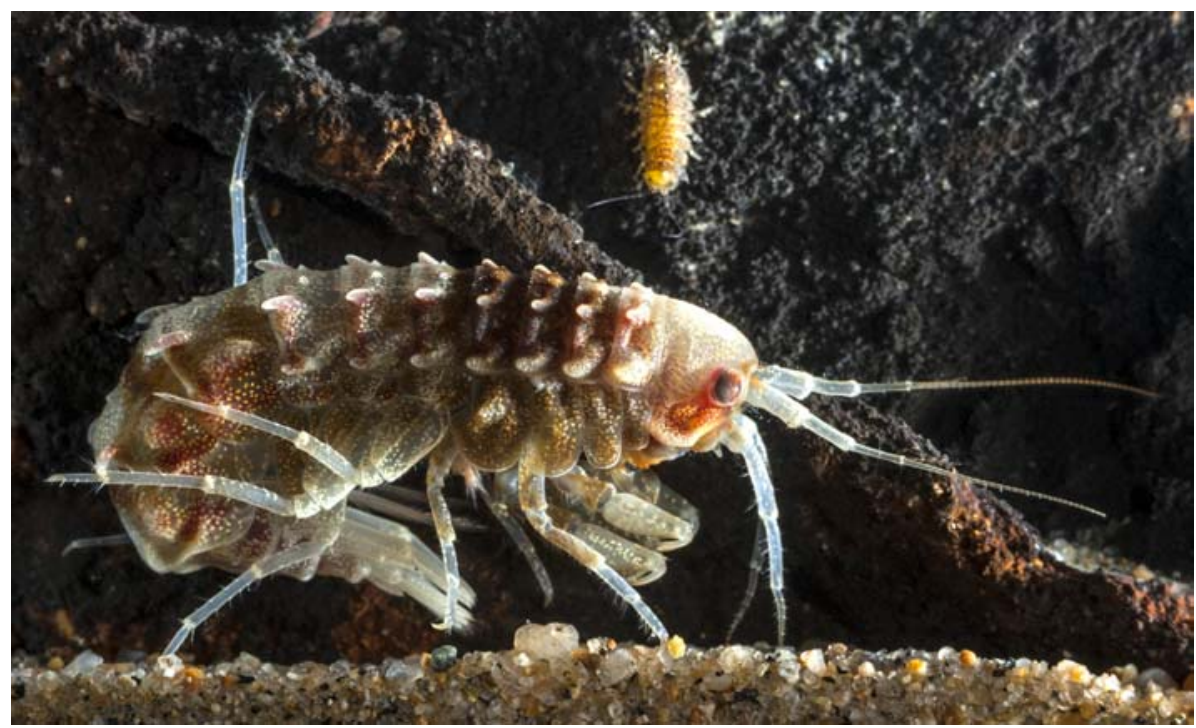

Fig. 25. Pallasea (Homalogammarus) brandtii brandtii (Dybowsky, 1874). Body length up to $30 \mathrm{~mm}$. Photo by S.I. Didorenko. Pис. 25. Pallasea (Homalogammarus) brandtii brandtii (Dybowsky, 1874). Длина тела до 30 мм. Фото С.И. Дидоренко.

pallasea plumose bristles in branches of uropods 3 are totally replaced by simple ones. Finally, the genus Hakonboeckia is highly peculiar: the interantennal lobes of the head are transformed into long triangular processes, and the lower edges of the mesosome segments extend ventrally and laterally in the form of triangular teeths.

COMPOSITION. Pallasea Bate, 1862 with subgenera Homalogammarus Bazikalova, 1945, Babr Kamaltynov et Väinölä, 2002, and Pentagonurus Sowinsky, 1915; Gymnogammarus Sowinsky, 1915; Hakonboeckia Stebbing, 1899; Leptostenus Bazikalova, 1945; Metapallasea Bazikalova,
1959; Poekilogammarus Sowinsky, 1915 with subgenera Bathygammarus Bazikalova, 1945, Inobsequentus Tachteew, 2000, Onychogammarus Sowinsky, 1915, Rostrogammarus Bazikalova, 1945, and Variogammarus Tachteew, 1995.

Subfamily Parapallaseinae Kamaltynov, 2009

Type genus: Parapallasea Stebbing, 1899.

DIAGNOSIS OF ARCHETYPE (Figs 27, 28). Large amphipods. Body robust, squeezed from sides, with a strong cuticle. At rest, the animals usually lie on his side. Segments 


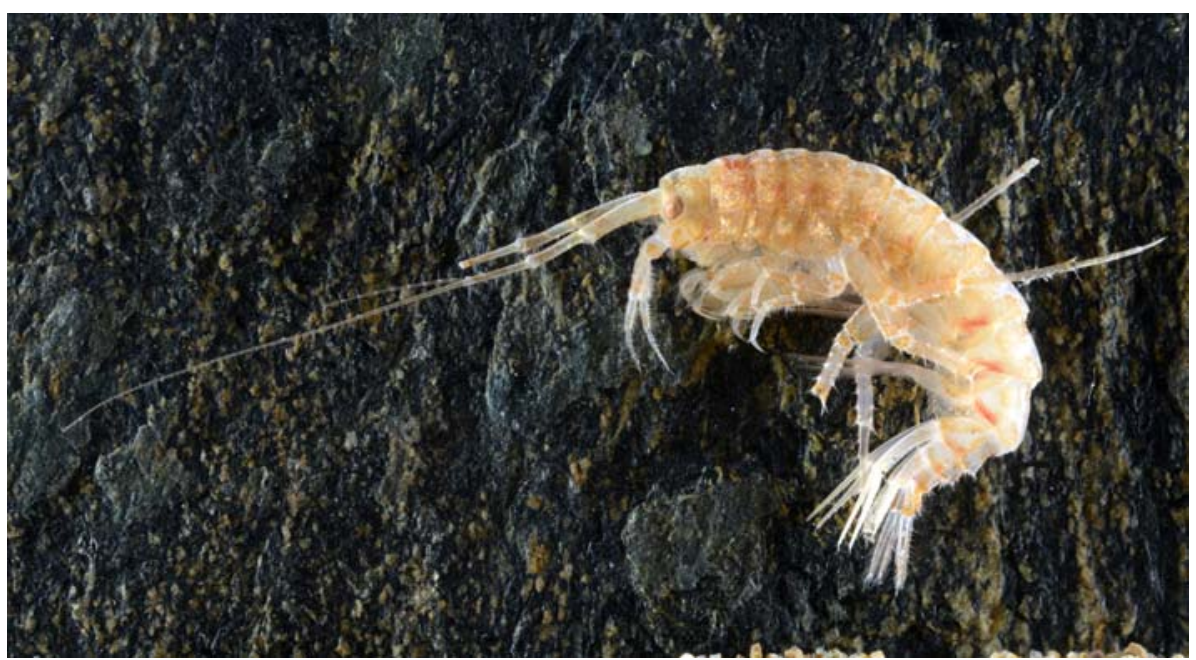

Fig. 26. Poekilogammarus (Poekilogammarus) sukaczewi Sowinsky, 1915. Form, intermediate between the genera Pallasea and Poekilogammarus. Body length up to $43 \mathrm{~mm}$. The right antenna flagellum is cut off. Photo by S.I. Didorenko.

Pис. 26. Poekilogammarus (Poekilogammarus) sukaczewi Sowinsky, 1915. Форма, промежуточная между родами Pallasea и Poekilogammarus. Длина тела до 43 мм. Жгут правой антенны оборван. Фото С.И. Дидоренко.

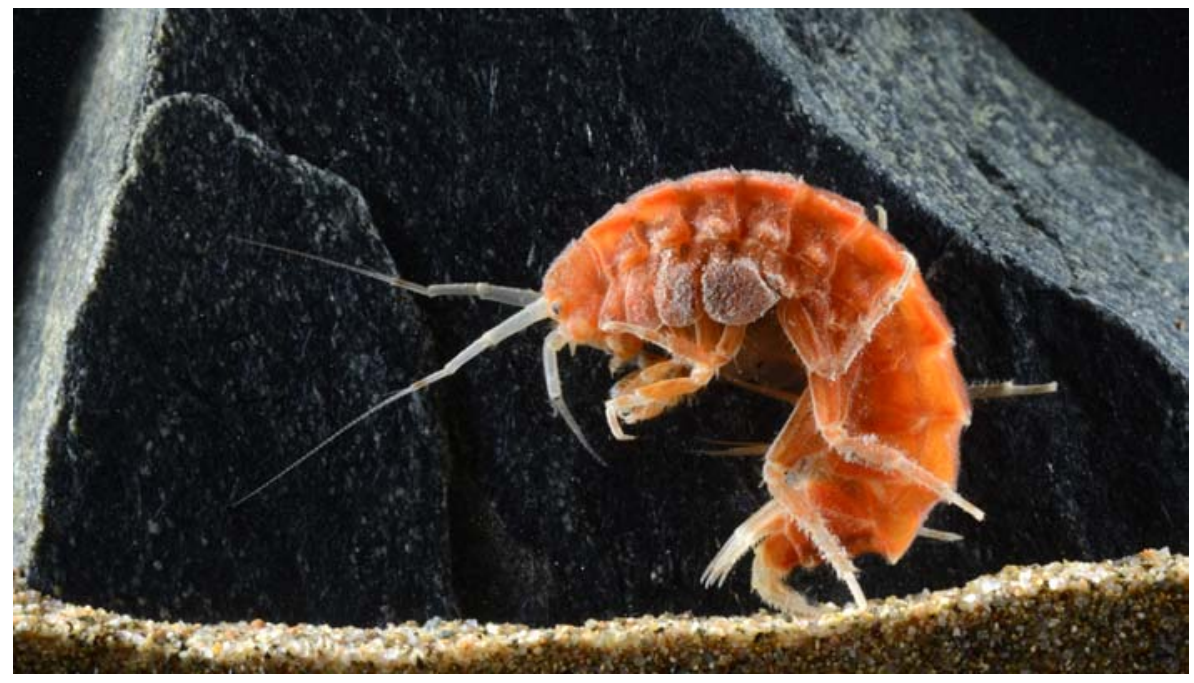

Fig. 27. Parapallasea puzyllii puzyllii (Dybowsky, 1874). Body length up to $50 \mathrm{~mm}$. Photo by S.I. Didorenko. Рис. 27. Parapallasea puzyllii puzyllii (Dybowsky, 1874). Длина тела до 50 мм. Фото С.И. Дидоренко.

of mesosome or part of them with lateral elevations in form of long keels or small teeths. Median row of elevations in form of very weak tubercles or absent. Head smooth on top. Eyes not wide, oblique or rounded, convex. Pereopods of moderate length. Bases 5-7 rather broad in upper part, narrowed down, without long setae on posterior margin. Uropod 1 and 2 primarily or only with spines. Uropods 3 well developed, always with variously developed plumose setae.

DEVIATIONS. Eyes can be small, point-shaped (but convex), in the deep-water species Parapallasea lagowskii (Dybowsky, 1874) they are small and depigmented. Marginal rows may be completely absent, with only groups of spines present: Ceratogammarus dybowskii Sowinsky, 1915, C. acerus Bazikalova, 1937.

COMPOSITION. Parapallasea Stebbing, 1899; Ceratogammarus Sowinsky, 1915.
Family Carinogammaridae Tachteew, 2000

Type genus: Carinogammarus Stebbing, 1899 (sensu Bazikalova [1975]).

DIAGNOSIS OF ARCHETYPE (Figs 29, 30). Amphipods of small and medium size (up to $10-20 \mathrm{~cm}$ ). Body slightly widened anteriorly. Median row of elevations in form of weak longitudinal keels or bumps on all or on part of the segments (at least two or three), lateral rows absent, marginal ones in form of weak blisters or absent. Head smooth, with wide, smoothly rounded interantennal lobes. Eyes always more or less pigmented. Coxal plates large, high, with smoothly rounded corners. Bases of pereopods 5 7 always with more or less developed posterior ("wingshaped") edge. Epimeral plates wide, with well expressed or only slightly posterolateral corners. Uropods 1 and 2 only with spines. Uropods 3 short, usually no more than $1 / 8$ of body length. 


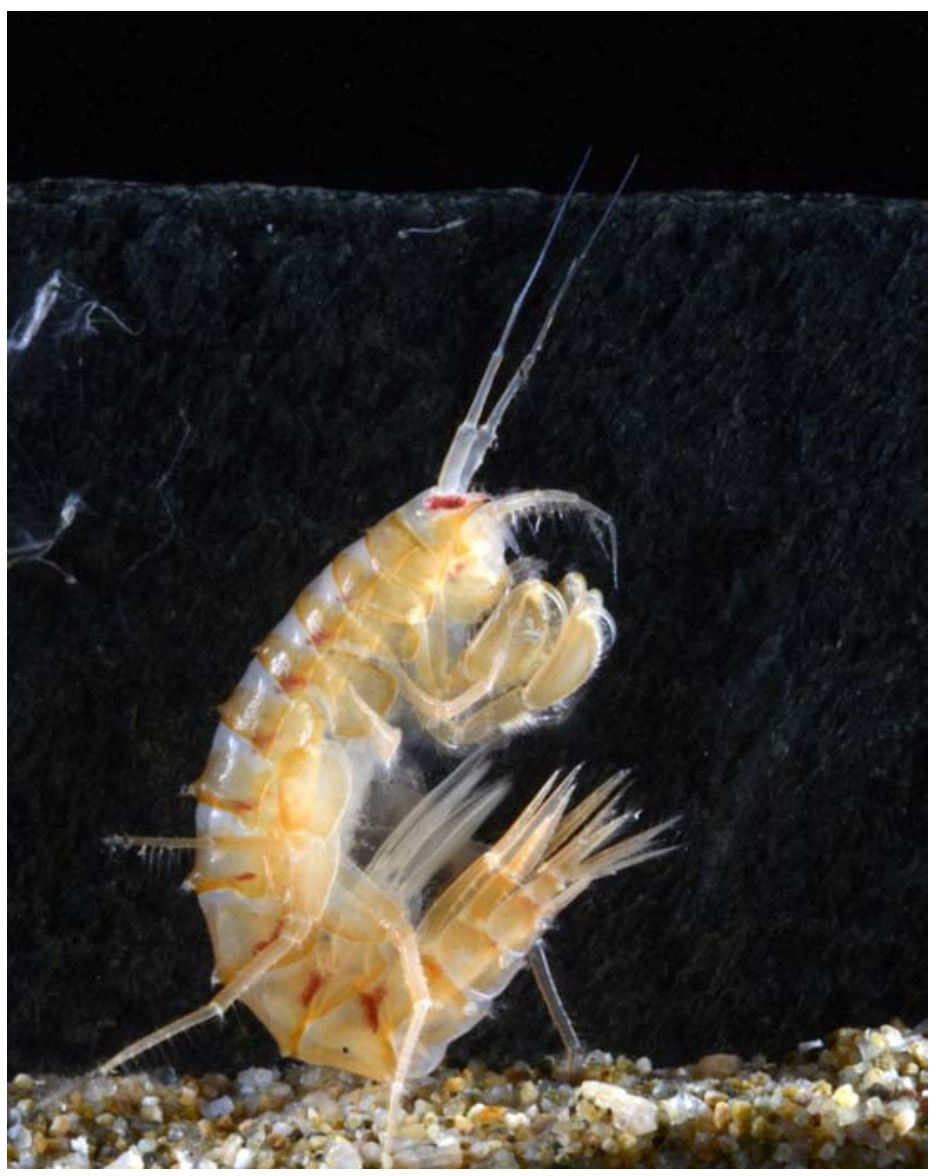

Fig. 28. Ceratogammarus cornutus (Sowinsky, 1915). Body length up to $30 \mathrm{~mm}$. Photo by S.I. Didorenko. Рис. 28. Ceratogammarus cornutus (Sowinsky, 1915). Длина тела до 30 мм. Фото С.И. Дидоренко.

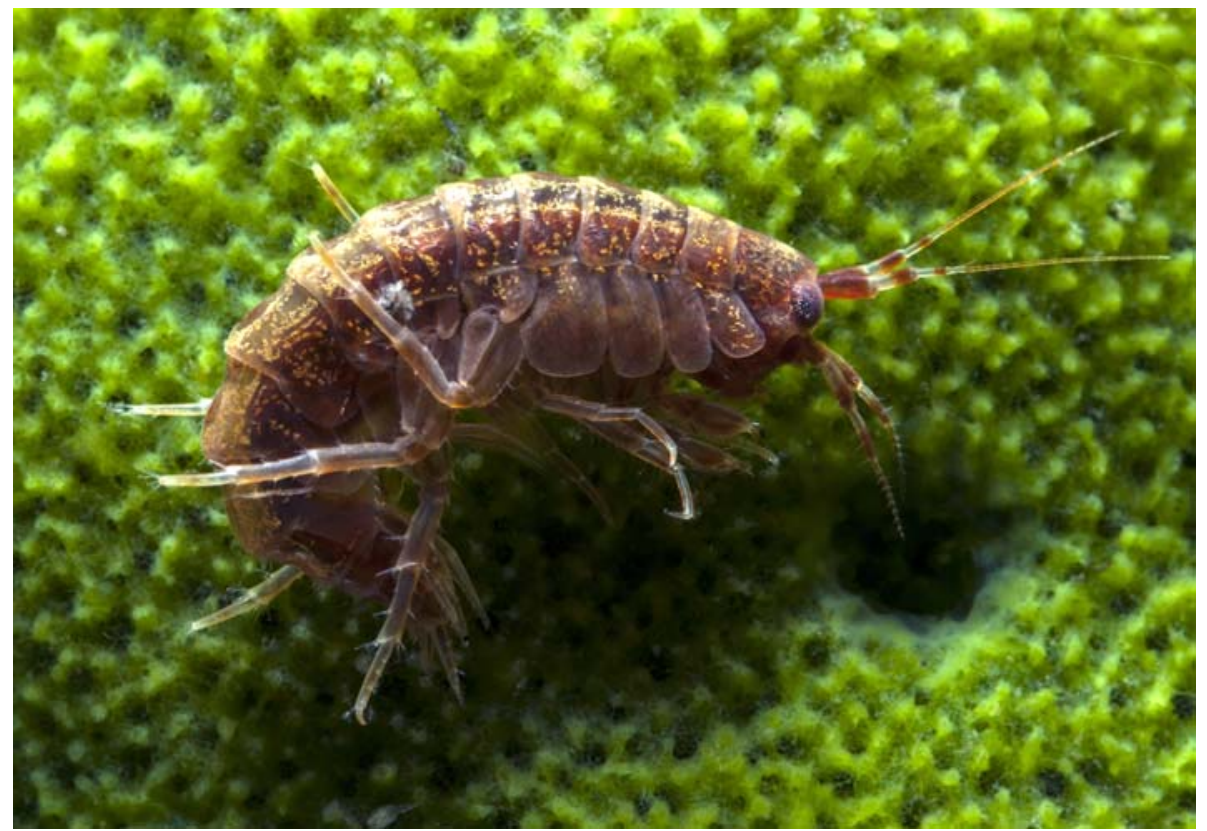

Fig. 29. Carinogammarus cinnamomeus (Dybowsky, 1874). Body length up to $17 \mathrm{~mm}$. Photo by S.I. Didorenko. Pис. 29. Carinogammarus cinnamomeus (Dybowsky, 1874). Длина тела до 17 мм. Фото С.И. Дидоренко. 


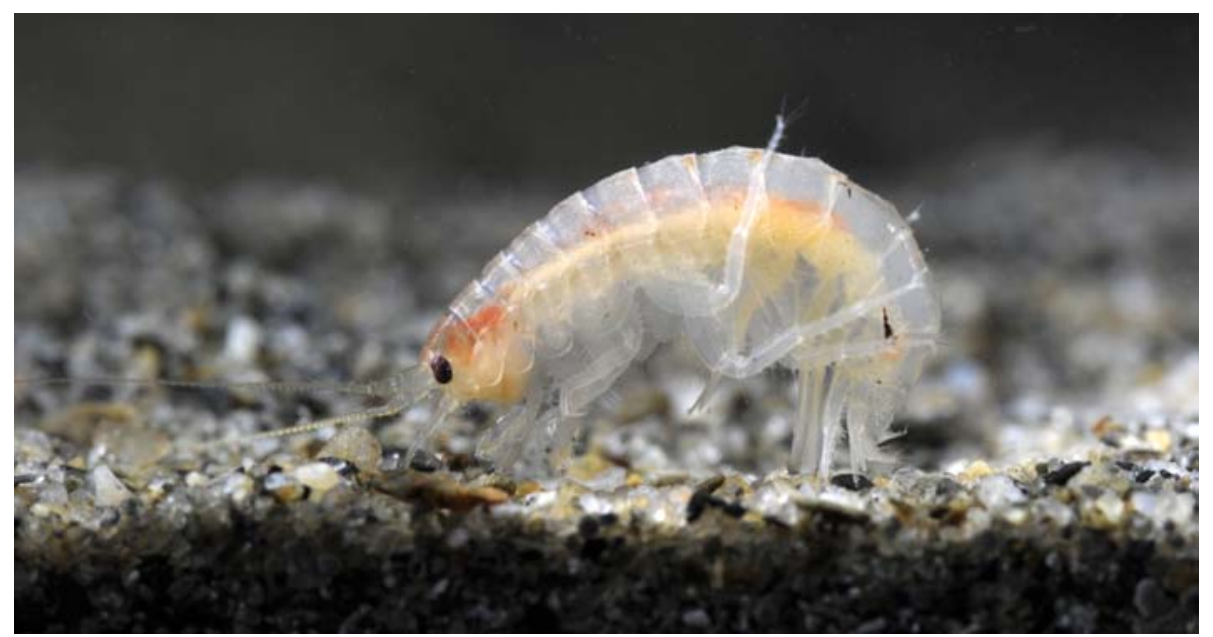

Fig. 30. Echiuropus (Asprogammarus) rhodophthalmus microphthalmus (Dybowsky, 1874). Body length up to $12-14 \mathrm{~mm}$. Photo by S.I. Didorenko.

Рис. 30. Echiuropus (Asprogammarus) rhodophthalmus microphthalmus (Dybowsky, 1874). Длина тела до 12-14 мм. Фото С.И. Дидоренко.

DEVIATIONS. The size and armature of uropods 3 greatly vary. They may bear spines, either with simple or with plumose setae. Some species are large-sized, with strongly developed median row of elevations and a separated from the front interantennal lobes: Carinogammarus wagii (Dybowsky, 1874). This is the most deviating species, characterized by the size up to $43 \mathrm{~mm}$, and by high median keels, assigned by some authors to the monotypic genus Eucarinogammarus Sowinsky, 1915. Bazikalova [1975, p. 33-35] argued for placing this species to Carinogammarus.

COMPOSITION. Carinogammarus Stebbing, 1899; Echiuropus Sowinsky, 1915 with subgenera Asprogammarus Bazikalova, 1975 and Smaragdogammarus Bazikalova, 1975; Gmelinoides Bazikalova, 1945; Pseudomicruropus Bazikalova, 1962.
Family Pachyschesidae Tachteew, 1998

Type genus: Pachyschesis Bazikalova, 1945 (by monotypy).

DIAGNOSIS OF ARCHETYPE (Figs 31-33). Small parasitic forms. Males much smaller than females or even dwarf. Adult females with swollen mesosoma and outstanding down voluminous marsupium. Body without armature, urosoma and all segments without spines. Eyes of live specimens red or pink, at fixed ones poorly marked or discolored. Interantennal lobes smoothly rounded. Antennae short, 1st pair is more than twice shorter than the body. Calceoli absent. Mouth parts weak. Gnathopods with a rather large almond-shaped propodus. Coxal plates 5-7 with rounded corners, in 5th pair anterior half high, much higher than posterior one, with a round lobe descending downwards.

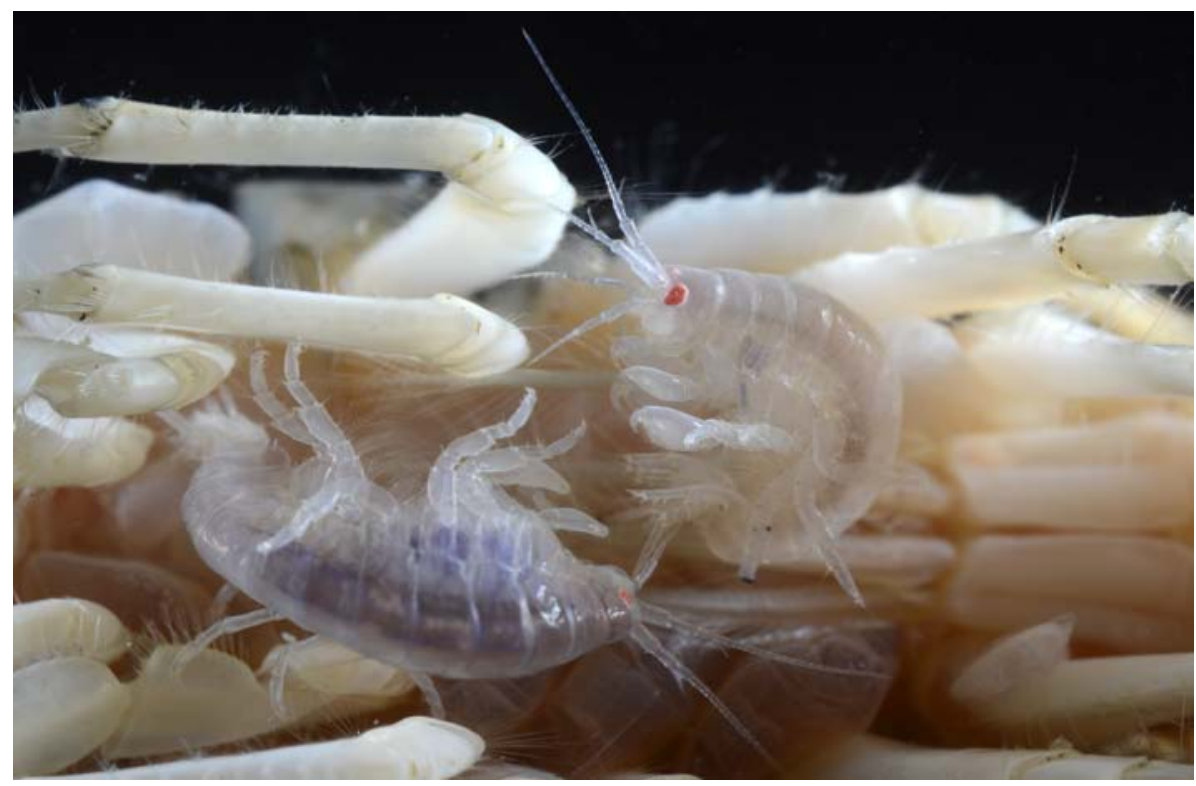

Fig. 31. Pachyschesis lamakini Tachteew, 2000 on the host, Garjajewia cabanisii, female and male (smaller). Body length of females up to $11.5 \mathrm{~mm}$, males up to $8 \mathrm{~mm}$ [Takhteev, 2000]. Photo by S.I. Didorenko.

Рис. 31. Pachyschesis lamakini Tachteew, 2000 на виде-хозяине Garjajewia cabanisii, самка и самец (более мелкий). Длина тела самок до 11,5 мм, самцов до 8 мм [Takhteev, 2000]. Фото С.И. Дидоренко. 


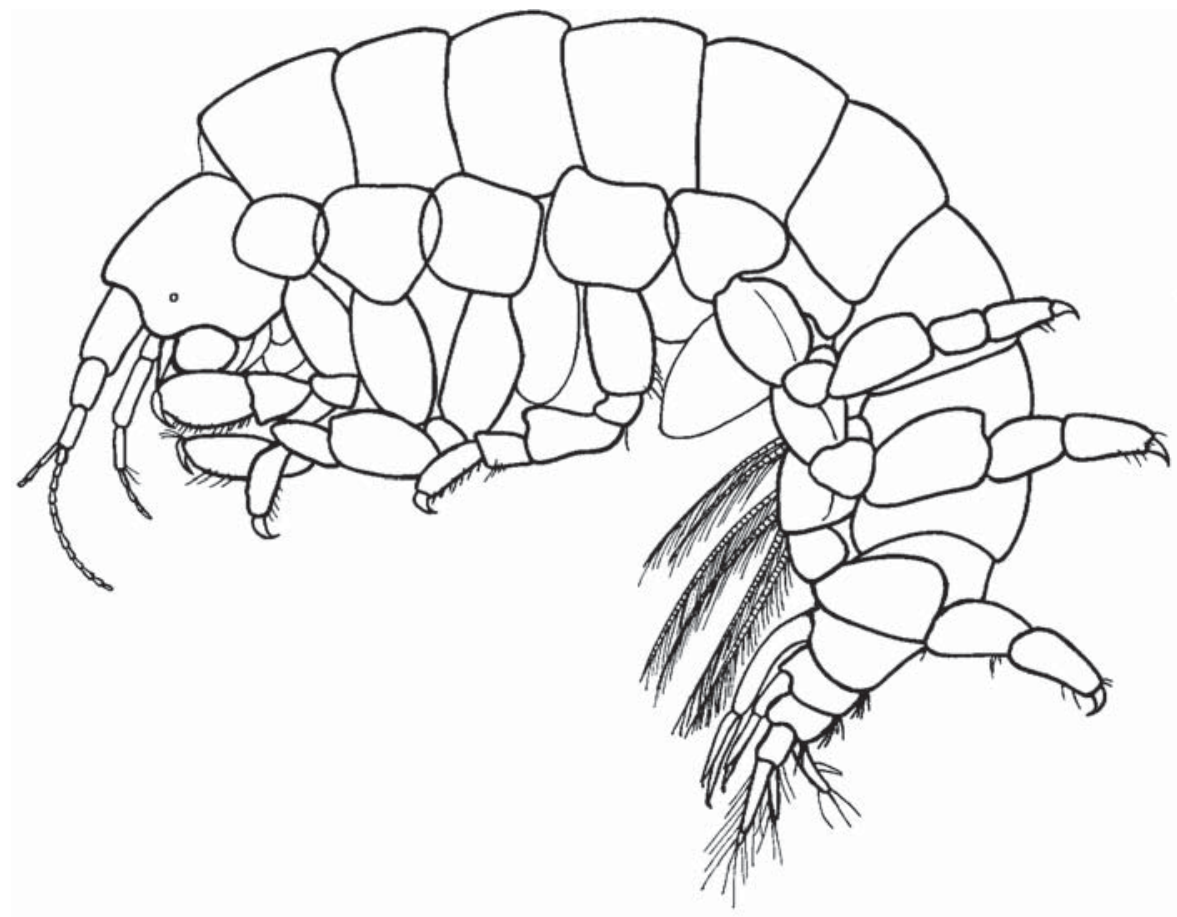

Fig. 32. Pachyschesis inquilinus Tachteew, 2000, female. Body length of females up to $14 \mathrm{~mm}$, males up to $6 \mathrm{~mm}$ [Takhteev, 2000]. Drawing by V.V. Takhteev.

Рис. 32. Pachyschesis inquilinus Tachteew, 2000, самка. Длина тела самок до 14 мм, самцов до 6 мм [Takhteev, 2000]. Рисунок В.В. Тахтеева.

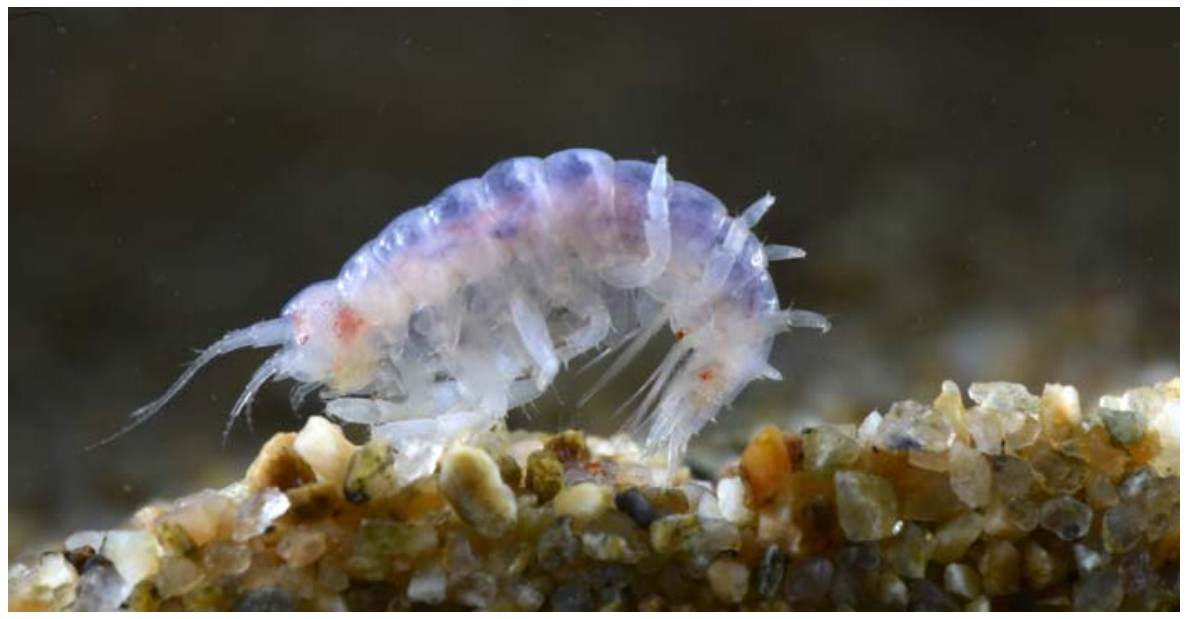

Fig. 33. Pachyschesis bazikalovae G. Karaman, 1976, female. Body length of females up to $14 \mathrm{~mm}$, males up to $8 \mathrm{~mm}$ [Takhteev, 2000]. Photo by S.I. Didorenko.

Рис. 33. Pachyschesis bazikalovae G. Karaman, 1976, самка. Длина тела самок до 14 мм, самцов до 8 мм [Takhteev, 2000]. Фото С.И. Дидоренко.

Pereopods form attachment apparatus, increased in length from 5 to 7 pair; bases with the setae, meri expanded, propodi forming subchaela, with marginal spines; claws strong, short. Epimeral plates with bundles of bristles. Uropods 3 with long simple setae. Telson setose.

COMPOSITION. Pachyschesis Bazikalova, 1945.

Family Macrohectopodidae Sowinsky, 1915

Type genus: Macrohectopus Stebbing, 1906 (on monotypy).
DIAGNOSIS OF ARCHETYPE (Fig. 34). Body is long, thin, translucent. The segments of the body are smooth, but at the posterior margins of the segments of metasoma at females formed the pointed protuberances. The eyes are black. Antennae 1 are equal to $2 / 3-3 / 4$ of the body length. The peduncles of antenna 1 thick, much thicker than the peduncles of antenna 2 . When swimming the antennae form the characteristic elbow bend, in which the animal is easily recognized. Accessory flagellum of antenna 1 absent, sometimes evident in the form of rudiment under a large increase. 


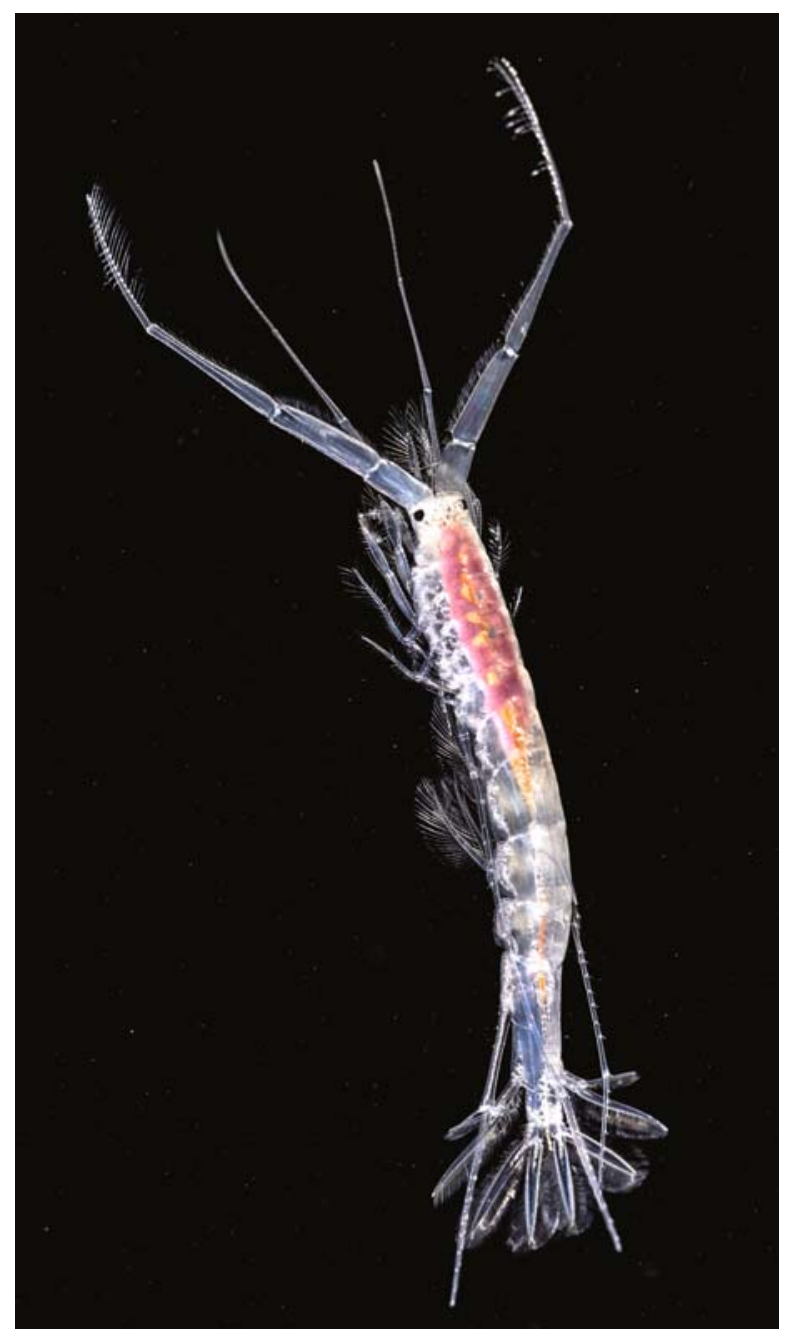

Fig. 34. Macrohectopus branickii (Dybowsky, 1874), female. Body length up to $38 \mathrm{~mm}$. Violet maturing oocytes are visible. Photo by S.I. Didorenko.

Рис. 34. Macrohectopus branickii (Dybowsky, 1874), самка. Длина тела до 38 мм. Видны фиолетовые созревающие ооциты. Фото С.И. Дидоренко.

Gnathopods are long, copiously covered with setae, together with the mouth appendages form a filter apparat to supply in the pelagic zone. Pereopods very thin and weak (thread-like), $6^{\text {th }}$ pair especially long. Uropods 1 very long, on the branches lack setae, the inner branch several times longer than the outer, and extends beyond the end of uropods 3. Uropods 2 with plumose setae. Branches of uropods 3 of equal length, lanceolate, external branch one-segmented. Both branches on both sides densely covered with plumose setae.

COMPOSITION. The only species and genus Macrohectopus branickii (Dybowsky, 1874) maintains an obligate pelagic lifestyle, with extensive vertical and horizontal migration, forming dense aggregations. The species is characterized by a pronounced sexual dimorphism in size: body length of mature females $14-38 \mathrm{~mm}$, males 3-6 mm. For complete morphological and ecological review see Timoshkin et al. [1995].

\section{Incertae sedis}

The diagnoses of several genera did not fit into any of the archetypes and their position remains uncertain. These genera can be metaphorically compared to lone stars wandering in intergalactic space. These include:

Lobogammarus Bazikalova, 1945, Macropereiopus Sowinsky, 1915, Polyacanthisca Bazikalova, 1937 (ultra-deep water, probably Pallaseidae; Fig. 35), Profundalia Kamaltynov, 2001 (probably Micruropodidae).

Below we present the key for identification archetypes of the families that we recognize (not regarding deviating species). To identify the genera of the Baikal

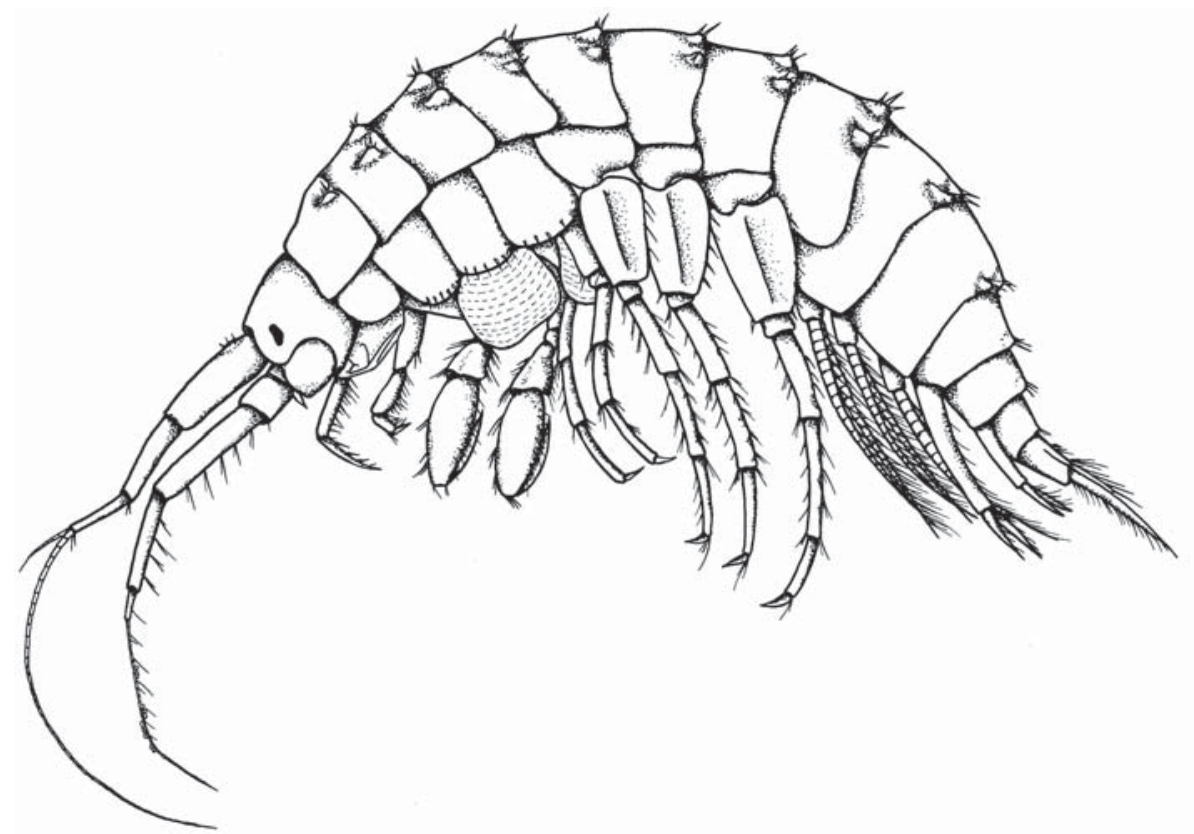

Fig. 35. Polyacanthisca calceolata Bazikalova, 1937. Body length up to $21 \mathrm{~mm}$ [Takhteev, 1996]. Drawing by I.V. Golenkova. Рис. 35. Polyacanthisca calceolata Bazikalova, 1937. Длина тела до 21 мм [Takhteev, 1996]. Рисунок И.В. Голенковой. 
amphipod (regardless of family) it is recommended to use our key recently published in Russian [Takhteev, Didorenko, 2015] and English [Sket, Morino, Takhteev, Rogers, 2019].

KEY TO IDENTIFY THE ARCHETYPES OF THE FAMILIES OF BAIKAL AMPHIPODS

1 (5) Significant cuticle outgrowth or weak elevations in at least one or three rows (median, lateral and/or marginal).

$2(3,4)$ Lateral rows of elevations most developed .... Pallaseidae

$3(2,4)$ Median and marginal rows of elevations, or only median row in part of segments most developed, in form of sharp teeth or high keels; lateral rows poorly developed or absent ............................. Acanthogammaridae

$4(2,3)$ Only median row of elevations in form of tubercles or very low keels at least at three segments of meso- and/ or metasoma are expressed ............. Carinogammaridae

5 (1) Cuticle outgrowth and elevations are absent in all or almost all segments. Body smooth, rarely with unclear blisters or with tubercles on two segments of mesosome.

6 (9) Antennae long, at least 1/2 body length, often longer than the body. Bases of pereopods 5-7 pairs with only very short (barely visible) setae on posterior margin or glabrous. Uropods 3 normally developed, not shorter than $1 / 8$ of the body length.

7 (8) Body compact, dense, bent along the median line of the back. Pereopods 5-7 moderate length, with conventional structure... Gammaridae

8 (7) Body elongate, slender, in floating and fixed specimens rectified. Pereopods 5-7 long, threadlike. Obligatory pelagic animals ....................... Macrohectopodidae

9 (6) Antennae short, shorter than $1 / 2$ body length. Bases of pereopods 5-7 with a more or less long bristles on hind margin. Uropods 3 short, shorter than $1 / 8$ of the body length or even rudimentary ......

10 (11) Pereopods very short and clingy, form attachment apparatus, subchelate-like about claws of gnathopods, tenacious claw adjacent to the wide distal end of propodus. Eyes of live specimens frequently red. Uropods 3 always with two-segmented outer branch. At least two segments in additional flagellum of antenna 1 Pachyschesidae

11 (10) Pereopods short, but of normal morphology, non subchelate (with one exception). Eyes most often black or brown. Uropod 3 with one- or two-segmented outer branch. Additional flagellum of antenna 1 one-segmented, rarely with a rudimentary second segment........

Micruropodidae

\section{Conclusion}

In the present study I have attempted to show that the archetypic approach helps to avoid taxonomic inflation. However, there is still a number of unresolved problems of systematization. Apparently, it is time to question the validity of "literature" revisions (i.e. based only on literature data), and if editors should avoid their publication. In the allocation of new species and genera, authors need to specify the original material that they have worked. There is a strong evidence that such literature "revisions" most often lead to consolidation of errors and unreasonable actions.
Another problem relates to "ghost species". These are species, which type material is lost, and the description is made so poor that it is impossible to identify them reliably in nature. The formal presence of them in the nomenclature biases the study of fauna composition. For example, "Ctenacanthus roseus", was described by Garjajew [1901] upon a single specimen. The generic name turned out to be nomen praeoccupatum, and the species is not included in any subsequent reports. Kamaltynov [2009] "resurrected" this species, called by him Garjajewia rosea, although no evidence of its affinity to the genus Garjajewia was given. The original description suggests that Garjajew [1901] described under this name the earlier known species Paragarjajewia petersii (Dybowsky, 1874). In particular, Garjajew's fig. II.11 clearly shows that the species does not possess a key characteristic of Garjajewia: serrated 5-th segment of the rod of the lower antenna and a jagged flagellum. At the same time, there is a short upturned rostrum characteristic for $P$. petersii, long antennae, a low medial row of elevations, etc. In the Kazan University, where Garjajew worked, no type material was found (R.M. Sabirov, pers. comm). Therefore, the status of this species remains dubious.

Therefore, it is recommended that "ghosts species" should not be included in the identification manuals, keys and taxonomical lists, despite the formal availability of their names.

The author hopes that the application of the archetypic approach described above will advance taxonomy of various polymorphic taxonomic groups of organisms, including the marine ones.

\section{Acknowledgements}

The author is sincerely grateful to S.I. Didorenko for the unique photos of live amphipods, and to all colleagues who participated in the discussion of the problem. My special thanks are due to Dr. Vassily A. Spiridonov, who completely corrected the English text of the manuscript. This study was supported by the grants from the Russian Foundation for Basic Research (\#\# 16-04-00786, 13-04-00614).

\section{References}

Baldauf S.L. 2008. An overview of the phylogeny and diversity of eukaryotes // Journal of Systematics and Evolution. Vol.46. No.3. P.263-273.

Barnard J.L., Barnard C.M. 1983. Freshwater Amphipoda of the world. Virginia: Mt. Vernon. 830 p.

Bazikalova A.Ya. 1935. [To the systematics of Baikal Amphipoda] // Trudy Baikalskoi Limnologicheskoi Stantsii. Vol.6. P.31-52 [in Russian].

Bazikalova A.Ya. 1945. [Les Amphipodes du Baïkal] // Trudy Baikalskoi Limnologicheskoi Stantsii. Vol.11. P.1-440 [in Russian, with French summary].

Bazikalova A.Ya. 1962. [Systematics, ecology and distribution of genera Micruropus Stebbing and Pseudomicruropus nov. gen. (Amphipoda, Gammaridea)] // Sistematika i ekologiya rakoobraznikh Baikala. Trudy Limnologicheskogo instituta. Vol.2 (22). Pt.1. P.3-140 [in Russian].

Bazikalova A.Ya. 1975. [To the systematics of Baikal amphipod (genera Carinogammarus Stebbing, Eucarinogammarus (Sow.) and Asprogammarus gen. n.)] // Novoye o faune Baikala. Part 1. Novosibirsk: Nauka Publ. P.31-81 [in Russian]. 
Bedulina D.S., Takhteev V.V., Pogrebnyak S.G., Govorukhina E.B., Madyarova E.V., Lubyaga Yu.A., Vereshchagina K.P., Timofeyev M.A., Luckenbach T. 2014. On Eulimnogammarus messerschmidtii, sp. n. (Amphipoda: Gammaridea) from Lake Baikal, Siberia, with redescription of E. cyanoides (Sowinsky) and remarks on taxonomy of the genus Eulimnogammarus // Zootaxa. Vol.3838. No.5. P.518-544. http://dx.doi.org/10. 11646/zootaxa.3838.5.2

Beklemishev V.N. 1994. [The methodology of systematics]. Moscow: KMK Scientific Press Ltd. 250 p. [In Russian]

[Benedict Dybowsky] 2000. Novosibirsk: Nauka Publ. 296 p. [In Russian]

Bousfield E.L. 1977. A new look at the systematics of gammaroidean amphipods of the world // Crustaceana. Suppl.4. P.282316.

Bousfield E.L. 1982a. Amphipoda. Gammaridea // S.P. Parker (ed.). Synopsis and classification of living organisms. New York: McGraw-Hill. Vol.2. P.254-285.

Bousfield E.L. 1982b. Amphipoda (Paleohistory) // Yearbook of Science \& Technology. McGraw-Hill. P.96-100.

Bousfield E.L. 1989. Revised morphological relationships within the amphipod genera Pontoporeia and Gammaracanthus and the "glacial relict" significance of their postglacial distributions // Canadian Journal of Fisheries and Aquatic Sciences. Vol.46. No.10. P.1714-1725.

Bousfield E.L., Shih C.-t. 1984. The phyletic classification of amphipod crustaceans: problems in resolution // Amphipacifica. Vol.1. No.3. P.76-134.

Daneliya M.E., Kamaltynov R.M., Kontula T., Väinölä R. 2009. Systematics of the Baikalian Babr (Crustacea: Amphipoda: Pallaseidae) // Zootaxa. Vol.2276. P.49-68. DOI: 10.5281/ zenodo. 191076

Daneliya M.E., Kamaltynov R.M., Väinölä R. 2011. Phylogeography and systematics of Acanthogammarus s. str., giant amphipod crustaceans from Lake Baikal // Zoologica Scripta. Vol.40. No.6. P.623-637. DOI: $10.1111 / \mathrm{j} .1463-6409.2011 .00490 . x$

Daneliya M.E., Väinölä R. 2014. Five subspecies of the Dorogostajskia parasitica complex (Dybowsky) (Crustacea: Amphipoda: Acanthogammaridae), epibionts of sponges in Lake Baikal // Hydrobiologia. Vol.739. No.1. P.95-117. http://dx.doi.org/ 10.1007/s10750-013-1671-x

Dorogostajsky V.Ch. 1916. [On the crustacean fauna of the Angara river] // Ezhegodnik Zoologicheskogo muzeya Rossiyskoy Akadimii nauk. Vol.21. No.4. P.302-322 [in Russian].

Dorogostajsky V.Ch. 1922. [Materials for carcinological fauna of Lake Baikal] // Trudy Komissii po izucheniyu ozera Baikala. Vol.1. No.2. P.105-153 [in Russian].

Dorogostajsky V.Ch. 1930. [New materials for the carcinological fauna of Lake Baikal] // Trudy Komissii po izucheniju ozera Baikala. Vol.3. P.49-76 [in Russian].

Dorogostajsky V.Ch. 1936. [Gammarids of the Barguzinsky Bay] // Izvestiya Biologo-geograficheskogo nauchno-issledovatel'skogo instituta pri Vostochno-Sibirskom gosudarsnvennom universitete. Vol.7. Nos.1-2. P.42-51 [in Russian].

Dybowsky B. 1874. Beiträge zur näheren Kenntnis der in dem Baikal-See vorkommenden niederen Krebse aus der Gruppe der Gammariden // Herausgegeben von der Russischen Entomologischen Gesellschaft zu St. Petersburg. St. Petersburg: Buchdruckerei von W. Besobrasoff und Comp. 190 S., 14 Taf

Foissner W., Blatterer H., Foissner I. 1988. The Hemimastigophora (Hemimastix amphikineta nov. gen., nov. spec.), a new protistan Phylum from Gondwanian Soils // European Journal of Protistology. Vol.23. No.4. P.361-383.

Garjajew V.P. 1901. [Gammarids of Lake Baikal. Part 1. Acanthogammarini] // Trudy Obshestva estestvoispytateley Imperatorskogo Kazanskogo universiteta. Vol.35. Is.6. 62 p. [In Russian]

Gruner H.-E., Moritz M., Dunger W. 1993. Lehrbuch der Speziellen Zoologie. Bd. 1. Wirbellose Tiere. Teil 4. Arthropoda (ohne Insecta). Jena: Gustav Fischer Verl. 1279 S.

Hackett J.D., Yoon H.S., Li S., Reyes-Prieto A., Rümmele S.E., Bhattacharya D. 2007. Phylogenomic analysis supports the monophyly of cryptophytes and haptophytes and the associa- tion of rhizaria with chromalveolates // Molecular biology and evolution. Vol.24. No.8. P.1702-1713. DOI: 10.1093/molbev/ msm089

Hou Zh., Li J., Li Sh. 2013. Ten new Gammarus species (Crustacea: Amphipoda: Gammaridae) from Yunnan-Guizhou Plateau, China // Zootaxa. Vol.3687. No.1. P.1-95. http://dx.doi. org/10.11646/zootaxa.3687.1.1

Hou Zh., Sket B. 2016. A review of Gammaridae (Crustacea: Amphipoda): the family extent, its evolutionary history, and taxonomic redefinition of genera // Zoological Journal of the Linnean Society. Vol.176. No.2. P.323-348. DOI: 10.1111/ zoj. 12318

Kamaltynov R.M. 1995. [Sister relationships of Baikal amphipods] // Vtoraja Vereshaginskaya Baikalskaya konferenciya, 5-10 October 1995. Abstracts and poster presentations. Irkutsk. P.74 [in Russian].

Kamaltynov R.M. 1999. On the higher classification of Lake Baikal amphipods // Crustaceana. Vol.72. No.8. P.933-944. http://dx. doi.org/10.1163/156854099503834

Kamaltynov R.M. 2001. Amphipoda: Gammaroidea // O.A. Timoshkin (ed.). Annotirovannyi spisok fauny ozera Baikal i ego vodosbornogo basseina [Index of animal species inhabiting Lake Baikal and its catchment area]. Vol.1: Ozero Baikal [Lake Baikal], Book 1. Novosibirsk: Nauka. P.572-831 [in Russian and English].

Kamaltynov R.M. 2009. Amphipoda: Gammaroidea in Angara and Yenisei River // O.A. Timoshkin (ed.). Annotirovannyi spisok fauny ozera Baikal i ego vodosbornogo basseina [Index of animal species inhabiting Lake Baikal and its catchment area]. Vol.2: Vodoemy i vodotoki Vostochnoi Sibiri i Severnoi Mongolii [Basins and Channels in the south of East Siberia and North Mongolia], Book 1. Novosibirsk: Nauka. P.297-329 [in Russian and English].

Karaman G.S. 1976. Contribution to the Knowledge of the Amphipoda 80. Revision of the genus Pachyschesis Bazik., 1945 from Baikal Lake (Fam. Gammaridae) // Пољопривреда и шумарство. Г.22. №3. Р.29-43.

Karaman G.S. 1977. Contribution to the Knowledge of the Amphipoda 81. Revision of the genus Carinurus Sow., 1915 from Baikal Lake (Fam. Gammaridae) // Пољопривреда и шумарство. Г.23. №1. Р.33-52.

Karaman G.S., Pinkster S. 1977. Freshwater Gammarus species from Europe, North Africa and adjacent regions of Asia (Crustacea - Amphipoda). Part II. Gammarus roeselii-group and related species // Bijdragen Tot De Dierkunde. Vol.47. P.165-196.

Keeling P.J., Burger G., Durnford D.G., Lang B.F., Lee R.W., Pearlman R.E., Roger A.J., Gray M.W. 2005. The tree of eukaryotes // Trends in Ecology and Evolution. Vol.20. No.12. P.670-676.

Lowry J.K., Myers A.A. 2013. A Phylogeny and Classification of the Senticaudata subord. nov. (Crustacea: Amphipoda) // Zootaxa. Vol.3610. No.1. P.1-80. http://dx.doi.org/10.11646/zootaxa.3610.1.1

Lyubarsky G.Yu. 1996. [Archetype, style, and rank in biological systematics]. Moscow: KMK Scientific Press Ltd. 434 p. [In Russian]

Lyubishev A.A. 1982. Problems of form, systematics and evolution of organisms: collected articles. Moscow: Nauka Publ. 281 p. [In Russian]

Mayr E. 1969. Principles of Systematic Zoology. New York: McGraw-Hill. 428 p.

McMenamin M.A.S., Zapata L.P., Hussey M.C. 2013. A triassic giant amphipod from Nevada, USA // Journal of Crustacean Biology. Vol.33. No.6. P.751-759. DOI: 10.1163/1937240X-00002192

Meyen S.V. 1978. [Main aspects of typology of organisms] // Zhurnal Obshchey Biologii. Vol.39. No.4. P.495-508 [in Russian].

Meyen S.V., Shreyder Yu.A. 1976. [Methodological aspects of classification theory] // Voprosy filosofii. No.12. P.67-79 [in Russian]

Morino H., Kamaltynov R.M., Nakai K., Mashiko K. 2000. Phenetic analysis, trophic specialization and habitat partitioning in the Baikal amphipod genus Eulimnogammarus (Crustacea) 
// Advances in Ecological Research. Vol.31. Ancient lakes: biodiversity, ecology and evolution. London: Academic Press. P.355-376.

Schram F.R. 1986. Crustacea. New York: Oxford University Press. $606 \mathrm{p}$.

Shatalkin A.I. 1988. Biological systematics. Moscow: Moscow University Publ. 184 p. [In Russian]

Sherbakov D.Yu., Kamaltynov R.M., Ogarkov O.B., Verheyen E. 1998. Patterns of evolutionary change in Baikalian gammarids inferred from DNA sequences (Crustacea, Amphipoda) // Molecular Phylogenetics and Evolution. Vol.10. No.2. P.160 167.

Shipunov A.B. 1999. [Fundamentals of the theory of systematics: A Training manual]. Moscow. 56 p. [In Russian]

Sket B., Morino H., Takhteev V., Rogers D.Ch. 2019. Phylum Arthropoda: Malacostraca: Amphipoda // Thorp and Covich's Freshwater Invertebrates. Fourth Edition. Volume IV: Keys to Palaearctic Fauna / D.Ch. Rogers, J.H. Thorp (ed.). London, San Diego, Cambridge, Oxford: Academic Press (Elsevier). P.808-836. https://doi.org/10.1016/B978-0-12-385024-9. $00022-8$

Sowinsky V.K. 1915. [Amphipoda of Lake Baikal] // Zoologicheskie issledovaniya ozera Baikala. Kiev. Vol.9. Is.1. 381 p., 37 plates [in Russian and German].

Starobogatov Ya.I. 1970. [Fauna of molluses and zoogeographical zoning of the continental waterbodies of the globe]. Leningrad: Nauka Publ. 372 p. [In Russian]

Starr H., Hegna Th., McMenamin, M.A.S. Epilogue to the tale of the triassic amphipod: Rosagammarus is a decapod tail (luning formation, Nevada) // General Paleontology (Posters), session No. 42. Wednesday, 20 May 2015. https:/gsa.confex.com/gsa 2015 NC/webprogram/Paper256121.html

Stebbing T.R.R. 1899. Amphipoda from the Copenhagen Museum and other sources. Part $2 / /$ Transactions of the Linnean Society of London. 2nd series. Zoology. Vol.7. No.2. P.25-45, pl. 6-14. http://dx.doi.org/10.1111/j.1096-3642.1897.tb00400.x

Stebbing T.R.R. 1906. Amphipoda I. Gammaridea // Das Tierreich. Eine Zusammenstellung und Kennzeichnung der rezenten Tierformen. 21. Lieferung. P.I-XXXIX, 1-806.

Takhteev V.V. (=Tachteew V.V.) 1995. The gammarid genus Poekilogammarus Stebbing, 1899, in Lake Baikal, Siberia (Crustacea Amphipoda Gammaridea) // Arthropoda Selecta. Vol.4. No.1. P.7-64.

Takhteev V.V. 1996. On the ecology of a rare species of amphipod, Polyacanthisca calceolata (Crustacea, Amphipoda) of Lake Baikal, with reference to parallelism in the evolution of the Baikal and oceanic deepwater faunas // Hydrobiological Journal. Vol.32. No.2. P.107-109.

Takhteev V.V. 1997. The gammarid genus Plesiogammarus Stebbing, 1899, in Lake Baikal, Siberia (Crustacea Amphipoda Gammaridea) // Arthropoda Selecta. Vol.6. Nos.1/2. P.31-54.

Takhteev V.V. 1998. [Parasite-hosts relationship between endemic Baikal amphipods] // Vzaimootnosheniya parazita i khozyaina. Vserossiyskaya mauchnaya konferentsiya, 8-10 Dek. 1998, Moskva. Tezisy dokladov. P.64 [in Russian].

Takhteev V.V. 2000. [Esseyes on the amphipods of Lake Baikal (systematic, comparative ecology, evolution)]. Irkutsk: Irkutsk Univ. Press. 350 p. [In Russian]
Takhteev V.V. 2001. Taxonomical system of Lake Baikal amphipods: a methodology and criterion for allocation of families // Fifth Internat. Crustac. Congress, Melbourne, Australia 9-13 July 2001. Melbourne: Univ. of Melbourne. P.138.

Takhteev V.V. 2012. [Problems of macrosystematics of Lake Baikal amphipods] // Aktual'nye problemy izucheniya rakoobraznykh kontinental'nykh vod: Sbornik lektsiy i dokladov Mezhdunarodnoi shkoly-konferentsii. Kostroma: Kostromskoi pechatnyi dom. P.293-296 [in Russian].

Takhteev V.V., Berezina N.A., Sidorov D.A. 2015. Checklist of the Amphipoda (Crustacea) from continental waters of Russia, with data on alien species // Arthropoda Selecta. Vol.24. No.3. P.335-370.

Takhteev V.V., Didorenko D.I. 2015. Fauna and ecology of amphipods of Lake Baikal: A Training manual. Irkutsk: V.B. Sochava Institute of Geography SB RAS Publisher. 116 p. [In Russian]

Takhteev V.V., Lopatovskaya O.G., Okuneva G.L., Pomazkova G.I., Samoilova E.A., Rozhkova N.A. 2017. Ecological description of the sodium chloride mineral springs in the Kirenga River basin and the upper reaches of the Lena River: 1 . General characteristics of the springs and their hydrofauna // Inland Water Biology. Vol.10. No.4. P.331-341. DOI: 10.1134/ S1995082917040101

Takhteev V.V., Mekhanikova I.V. 2000. [New species of amphipods (Crustacea Amphipoda) from the mountain streams of Khamar-Daban Ridge] // V.V. Takhteev (ed.). Issledovaniya vodnykh ekosistem Vostochnoi Sibiri. Irkutsk: Irkutsk State University Press. P.115-123 [in Russian, with English summary].

Taliev D.N. 1940. [Experience in applying the precipitation reaction to the knowledge of the origin and history of the Baikal fauna] // Trudy Baikalskoi Limnologicheskoi Stantsii. Vol.10. P.241-355 [in Russian, with English summary].

Tikhonenkov D.V., Janouskovec J., Mylnikov A.P., Mikhailov K.V., Simdyanov T.G., Aleoshin V.V., Keeling P.J. 2014. Description of Colponema vietnamica sp. $\mathrm{n}$. and Acavomonas peruviana $\mathrm{n}$. gen. n. sp., two new alveolate Phyla (Colponemidia nom. nov. and Acavomonidia nom. nov.) and their contributions to reconstructing the ancestral state of alveolates and eukaryotes // PLoS ONE. Vol.9, No.4. e95467. DOI: 10.1371/ journal.pone.0095467

Timoshkin O.A., Mekhanikova I.V., Shubenkov S.G. 1995. [Morphological features of Macrohectopus branickii] // Atlas i opredelitel' pelagobiontov Baikala (s kratkimi ocherkami po ikh ekologii). Novosibirsk: Nauka Publ. P.485-511 [in Russian].

WoRMS. 2019. World Register of Marine Species. WoRMS source details. http://www.marinespecies.org/aphia.php? $\mathrm{p}=$ sourcedetails\&id=201196 (last access 25.07.2019).

Wysocka A., Grabowski M., Sworobowicz L., Burzynski A., Kilikowska A., Kostoski G., Sell J. 2013. A tale of time and depth: intralacustrine radiation in endemic Gammarus species flock from the ancient Lake Ohrid // Zoological Journal of the Linnean Society. Vol.167. No.3. P.345-359. DOI: 10.1111/j.10963642.2012.00878.x

Responsible editors V.A. Spiridonov, K.G. Mikhailov 